Review

\title{
Are melatonin doses employed clinically adequate for melatonin-induced cytoprotection?
}

\author{
Daniel P. Cardinali* \\ Faculty of Medical Sciences, Pontificia Universidad Católica Argentina, Buenos Aires, Argentina. \\ *Correspondence: daniel_cardinali@uca.edu.ar; danielcardinali@ fibertel.com.ar; Tel: +54 11 \\ 43490200 ext 1192
}

Running title: Melatonin dose in clinical practice

Received: May 1, 2019; Accepted: June 3, 2019

\begin{abstract}
This review article discusses the special role that melatonin, a molecule with chronobiotic/cytoprotective properties, may have in prevention and treatment of the metabolic syndrome (MS), ischemic and non-ischemic cardiovascular diseases and Alzheimer's disease (AD). Prevention of these diseases is a major goal for governmental and non-governmental organizations, and melatonin, an unusual phylogenetically conserved molecule present in all aerobic organisms, merits consideration in this respect. In humans, circulating melatonin levels are consistently reduced in MS, ischemic and non-ischemic cardiovascular diseases and $\mathrm{AD}$, the potential therapeutic value of melatonin being suggested by a limited number of clinical trials generally employing melatonin in the 2-5 mg/day range. In animal model studies of MS, ischemic and non-ischemic cardiovascular diseases and AD melatonin was very effective to curtail symptomatology. However, calculations derived from animal studies indicate projected cytoprotective melatonin doses for humans in the 40-100 mg/day range, doses that are rarely employed clinically. Hence, controlled studies employing melatonin doses in this range are urgently needed. Since the pharmaceutical industry is refractive to support them because of the lack of protective patents for a natural compound, only the involvement of governmental and non-profit organizations can achieve that goal. Within this prospect, the off-label use of melatonin is discussed.
\end{abstract}

Keywords: aging; Alzheimer's disease; cytoprotection; inflammation; melatonin; metabolic syndrome; mild cognitive impairment; neurodegeneration; off-label use; oxidative stress.

\section{INTRODUCTION}

Chronic, endemic disorders such as the metabolic syndrome (MS) and Alzheimer's disease (AD) are major health problems and their prevention is presently a fundamental goal for governmental and non-governmental organizations. The prevalence of MS varies from 15 to 30\% depending on the region of the world considered $(1,2)$. An increase of 1.5 to 2.5 times in cardiovascular mortality occurs when MS is present.

$\mathrm{AD}$ and related dementia are disorders characterized by a progressive deterioration of the structure and function of the brain, with symmetric losses of neurons in the cognitive, motor or sensory systems. Several interrelated processes, such as free radical-mediated damage, mitochondrial dysfunction, low degree of inflammation and excitotoxicity, have been identified as pathophysiological mechanisms for 
neuronal death $(3,4)$. The global prevalence of dementia among people aged $\geq 60$ years is $5 \%$ to $7 \%$ (5). In 2010, approximately 35.6 million people lived with dementia, and this number is expected to double every 20 years. Approximately two-thirds of dementia cases are attributed to AD. The prevalence of dementia increases exponentially with age. For the age-group of 60 to 64 years, the prevalence is $2 \%$ and $0.6 \%$ for Caucasian and Chinese people, respectively; while for the age-group of 80 to 84 years, it increases to $13 \%$ and $9.4 \%$, respectively. The annual incidence rate (per 1000 individuals) of dementia worldwide was estimated to be 7.5 (6). Although the regular intake of antioxidants has been recommended for prevention of neurodegenerative diseases in ageing, the effectiveness of this treatment has been discussed (7). In this context, the use of melatonin as a cytoprotective agent merits consideration.

Melatonin, an unusual phylogenetically conserved compound present in all known aerobic phyla, has a promising significance as a cytoprotective molecule in addition to its chronobiotic properties (8). The pineal gland is the demonstrable source of circulating melatonin in humans, the decrease in plasma melatonin being one of the characteristics of the advancing age (9). This article is focused on the clinical use of melatonin in obesity-related disorders and AD. The discussion of the basic biological data is restricted to its relevance for melatonin doses potentially employable in humans. Medical literature was identified by searching databases including (MEDLINE, EMBASE), bibliographies from published literature and clinical trial registries / databases. Searches were last updated on May 1, 2019.

\section{BASIC BIOLOGY OF MELATONIN RELEVANT FOR CYTOPROTECTION}

As a chronobiotic / cytoprotective agent, melatonin occupies a special place in the prevention and treatment of MS and AD $(10,11)$. Melatonin improves sleep efficiency and has antioxidant and antiinflammatory properties, in part because of its function as a metabolic regulator and mitochondrial protector (12-14). Melatonin, an unusually phylogenetic conserved molecule present in all known aerobic organisms, is effective both as a chronobiotic and as a cytoprotective agent.

The light-dark variation in the synthesis of melatonin by pinealocytes is the essential fact that explains the role of melatonin as a chronobiotic that coordinates the physiology of biological rhythms (15). The action of melatonin as a chronobiotic is twofold: on the one hand, it "opens the doors of sleep" by inhibiting the promoting activity of late awakening driven by suprachiasmatic nuclei (SCN) $(16,17)$. On the other hand, melatonin is the "hormone of darkness", a chemical code of the duration of the night, and has established itself as crucial in the transmission of information from light to the neuroendocrine system. Melatonin represents a "hand" of the biological clock in the sense that it responds to the signals of the SCN, the temporal variation of the melatonin rhythm indicating the state of the clock, both in terms of phase (time in the internal clock in relation to external time) and amplitude (18).

In mammals, circulating melatonin is derived almost exclusively from the pineal gland (9). In addition, melatonin is synthesized locally in many cells, tissues and organs, including lymphocytes, bone marrow, thymus, gastrointestinal tract, skin and eyes, where it can play an autocrine or paracrine role (19). Indeed, there is now strong evidence that melatonin is produced in every animal cell that has mitochondria $(20,21)$. In both animals and humans, melatonin participates in diverse physiological functions that indicate not only the duration of the night, but also improve the elimination of free radicals and the immune response, showing relevant cytoprotective properties (22).

The chronobiotic action of melatonin is mediated via the melatonin receptors, which have been identified both in the CNS and in the periphery (23). $\mathrm{MT}_{1}$ and $\mathrm{MT}_{2}$ receptors all belonging to the superfamily of membrane receptors associated with $\mathrm{G}$ proteins (G-protein coupled receptors, GPCR) have been cloned. More recently, another member, GPR50, was included in the melatonin receptor subfamily. GPR50 shows high sequence homology to $\mathrm{MT}_{1}$ and $\mathrm{MT}_{2}$ but does not bind to melatonin or 
any other known ligand. An interesting feature of these receptors is their capacity to form homo- and heteromers between each other and also with other GPCRs (24).

Due to its liposolubility, melatonin penetrates all membranes and is associated with cytoplasmic proteins such as calmodulin and tubulin, which causes important changes in the cytoskeleton (25). Melatonin also accesses the cell nucleus where it may act indirectly via sirtuin-1 activation of the oscillator component ROR $\alpha$ (26).

The cytoprotective activity of melatonin exceeds that mediated via receptors. Almost every cell in the human body contains melatonin, in quantities much higher than those circulating in blood derived from the pineal gland (19). The mitochondrial capacity to synthesize melatonin is now confirmed, but for reasons that remain unexplained, intracellular melatonin does not get the extracellular space. To modify intracellular melatonin levels, doses much higher than those employed as a chronobiotic are needed $(27,28)$. Most studies on neuroprotective and anti-inflammatory effects in animals employ pharmacological doses, which clearly exceed the saturation of the receptor.

In both the cytoplasm and the cell nucleus, melatonin has important antioxidant and scavenging effects on free radicals, which are largely independent of receptors (29). These effects are exerted in three ways: (a) melatonin is a free radical scavenger; (b) melatonin is metabolized to compounds with high antioxidant activity; (c) melatonin is an indirect antioxidant, which stimulates the synthesis of antioxidant enzymes and inhibits that of prooxidant enzymes. Melatonin has a proven superiority to vitamin $\mathrm{C}$ and $\mathrm{E}$ in protection against oxidative damage and in the elimination of free radicals (30). In addition, melatonin potentiates the effects of other antioxidants, such as vitamin $\mathrm{C}$ and Trolox. Several antiapoptotic and cytoprotective effects of melatonin are exerted under conditions of ischemia (unrelated to free radicals) and can be attributed to the stabilizing activity of the mitochondrial membrane (28).

Melatonin is also an immunological modulator that shows proinflammatory and anti-inflammatory properties $(31,32)$. The anti-inflammatory actions are of medicinal interest, since they are observed in high-grade inflammation such as sepsis, ischemia/reperfusion and brain injury, as well as in the lowgrade inflammation seen in MS, neurodegenerative disorders and aging. Melatonin has significant antiinflammatory properties presumably by inhibiting the binding of nuclear factor $\kappa \mathrm{B}(\mathrm{NF} \kappa \mathrm{B})$ to $\mathrm{DNA}$, thus decreasing the synthesis of proinflammatory cytokines, by inhibiting cyclooxygenase (Cox) (33) in particular Cox- 2 (34), and by suppressing the expression of the inducible gene of nitric oxide synthase (35). In addition, other pathways of secondary signaling are involved (32).

\section{EVIDENCE FOR THE THERAPEUTIC VALUE OF MELATONIN IN ANIMAL MODELS OF MS}

Treatment with melatonin in rats can reduce obesity, type 2 diabetes and hepatic steatosis $(36,37)$. In several animal models of hyperadiposity, the injection of melatonin could normalize most of the observed alterations and correct the altered biochemical proinflammatory profile (Table 1). In addition, melatonin is effective in animal models of ischemic and nonischemic heart failure, an important comorbidity of MS (Table 2).

Melatonin treatment of streptozotocin-induced type 1 diabetic rats induces the regeneration and proliferation of $\beta$-cells in the pancreas leading to a decrease in blood glucose (38) (Table 1). Loss of melatonin in circulation after pinealectomy results in hyperinsulinemia and accumulation of triglycerides in the rat liver (39). The long-term administration of melatonin improves lipid metabolism in type 2 diabetic rats via restoring insulin sensitivity (40). Melatonin treatment increases glycogen content in the liver of rats (41) while in high fat diet-induced diabetic mice the intraperitoneal injection of $10 \mathrm{mg} / \mathrm{kg}$ melatonin improved glucose utilization and insulin sensitivity and ameliorated hepatic steatosis (42). 
Table 1. Effect of melatonin on animal models of MS. The human equivalent dose (HED) of melatonin for a $75 \mathrm{~kg}$ adult is calculated by normalization of body surface area (43)

\begin{tabular}{|c|c|c|c|}
\hline Findings & $\begin{array}{l}\text { Melatonin } \\
\text { Dose }\end{array}$ & $\begin{array}{l}\text { Daily HED } \\
\text { for a } 75 \mathrm{~kg} \\
\text { adult }\end{array}$ & Ref \\
\hline $\begin{array}{l}\text { In rats fed from weaning with a high-fat diet melatonin } \\
\text { decreased body weight gain, feed efficiency and plasma } \\
\text { glucose, leptin and triglyceride levels }\end{array}$ & $\begin{array}{l}30 \\
\mathrm{mg} / \mathrm{kg} / \text { day } \\
\text { p.o. }\end{array}$ & $365 \mathrm{mg}$ & (44) \\
\hline $\begin{array}{l}\text { In high-fat diet-fed mice, melatonin improved insulin } \\
\text { sensitivity and glucose tolerance }\end{array}$ & $\begin{array}{l}100 \\
\mathrm{mg} / \mathrm{kg} / \text { day } \\
\text { p.o. }\end{array}$ & $610 \mathrm{mg}$ & (45) \\
\hline $\begin{array}{l}\text { In ovariectomized rats, melatonin was effective to reduce } \\
\text { obesity }\end{array}$ & $\begin{array}{l}2-3 \mathrm{mg} / \mathrm{kg} \\
\text { p.o. }\end{array}$ & $25-36 \mathrm{mg}$ & $(46-48)$ \\
\hline $\begin{array}{l}\text { In olanzapine-treated rats, melatonin was effective to reduce } \\
\text { obesity }\end{array}$ & $\begin{array}{l}0.05 \mathrm{mg} / \mathrm{kg} \\
\text { p.o. }\end{array}$ & $0.6 \mathrm{mg}$ & (49) \\
\hline $\begin{array}{l}\text { Melatonin and its analog piromelatonin inhibited weight } \\
\text { gain and improve insulin sensitivity in high-fat fed rats }\end{array}$ & $\begin{array}{l}5 \mathrm{mg} / \mathrm{kg} \\
\text { p.o. }\end{array}$ & $60 \mathrm{mg}$ & (50) \\
\hline $\begin{array}{l}\text { In high-fat fed rats, melatonin attenuated body weight } \\
\text { increase, the increase in plasma glucose, insulin, } \\
\text { adiponectin, leptin, triglycerides and cholesterol levels, and } \\
\text { counteracted disrupted } 24 \mathrm{~h} \text { patterns }\end{array}$ & $\begin{array}{l}2.3 \mathrm{mg} / \mathrm{kg} \\
\text { p.o. }\end{array}$ & $25 \mathrm{mg}$ & (51) \\
\hline $\begin{array}{l}\text { Melatonin improves inflammation processes in liver and } \\
\text { pancreas of senescence-accelerated prone male mice } \\
\text { (SAMP8) }\end{array}$ & $\begin{array}{l}1 \mathrm{mg} / \mathrm{kg} \\
\text { p.o. }\end{array}$ & $6 \mathrm{mg}$ & $(52,53)$ \\
\hline $\begin{array}{l}\text { Melatonin improved mitochondrial function and increased } \\
\text { life span in SAMP8 mice }\end{array}$ & $\begin{array}{l}10 \mathrm{mg} / \mathrm{kg} \\
\text { p.o. }\end{array}$ & $60 \mathrm{mg}$ & (54) \\
\hline $\begin{array}{l}\text { Melatonin reduced body weight gain, visceral adiposity, } \\
\text { blood triglyceride and insulin levels and TBARS under a } \\
\text { high calorie diet in rats. }\end{array}$ & $\begin{array}{l}4 \mathrm{mg} / \mathrm{kg} \\
\text { p.o. }\end{array}$ & $48 \mathrm{mg}$ & (55) \\
\hline $\begin{array}{l}\text { In young male Zucker diabetic fatty rats melatonin } \\
\text { treatment reduced mean weight gain without affecting food } \\
\text { intake, decreased in a non-significant way blood pressure, } \\
\text { and improved dyslipidemia }\end{array}$ & $\begin{array}{l}10 \mathrm{mg} / \mathrm{kg} \\
\text { p.o. }\end{array}$ & $120 \mathrm{mg}$ & (56) \\
\hline $\begin{array}{l}\text { Melatonin improves MS induced by high fructose intake in } \\
\text { rats without affecting food intake }\end{array}$ & $\begin{array}{c}2.3 \text { to } 20 \\
\mathrm{mg} / \mathrm{kg} \text { p.o. }\end{array}$ & $25-120 \mathrm{mg}$ & $(57-61)$ \\
\hline $\begin{array}{l}\text { Melatonin and its analog piromelatonin reduced blood } \\
\text { pressure in spontaneously hypertensive rats }\end{array}$ & $\begin{array}{l}5 \mathrm{mg} / \mathrm{kg} \\
\text { p.o. }\end{array}$ & $60 \mathrm{mg}$ & (62) \\
\hline $\begin{array}{l}\text { Melatonin prevents the development of the MS in male rats } \\
\text { exposed to different light/dark regimens }\end{array}$ & $\begin{array}{l}120 \mathrm{mg} / \mathrm{kg} \\
\text { p.o. }\end{array}$ & $1.45 \mathrm{~g}$ & (63) \\
\hline $\begin{array}{l}\text { Melatonin attenuates high fat diet-induced fatty liver } \\
\text { disease in rats }\end{array}$ & $\begin{array}{c}5-10 \\
\mathrm{mg} / \mathrm{kg} \mathrm{p.o.}\end{array}$ & $60-120 \mathrm{mg}$ & (64) \\
\hline $\begin{array}{l}\text { Melatonin ameliorates low-grade inflammation and } \\
\text { oxidative stress in young Zucker diabetic fatty rats }\end{array}$ & $\begin{array}{l}10 \mathrm{mg} / \mathrm{kg} \\
\text { p.o. }\end{array}$ & $120 \mathrm{mg}$ & (65) \\
\hline $\begin{array}{l}\text { Melatonin improves hyperglycemia, hypertriglyceridemia, } \\
\text { polyphagia, and polydipsia in streptozotocin diabetic rats }\end{array}$ & $\begin{array}{c}2.5 \text { to } 20 \\
\mathrm{mg} / \mathrm{kg} \mathrm{p.o.}\end{array}$ & $25-240 \mathrm{mg}$ & $(66,67)$ \\
\hline
\end{tabular}




\begin{tabular}{|c|c|c|c|}
\hline $\begin{array}{l}\text { Protective effects of melatonin against metabolic and } \\
\text { reproductive disturbances in polycystic ovary syndrome in } \\
\text { rats }\end{array}$ & $\begin{array}{l}1-2 \mathrm{mg} / \mathrm{kg} \\
\text { i.p. }\end{array}$ & $12-24 \mathrm{mg}$ & (68) \\
\hline $\begin{array}{l}\text { Melatonin normalizes clinical and biochemical parameters } \\
\text { of mild inflammation in diet-induced MS syndrome in rats }\end{array}$ & $\begin{array}{l}2.3 \mathrm{mg} / \mathrm{kg} \\
\text { p.o. }\end{array}$ & $25 \mathrm{mg}$ & (69) \\
\hline $\begin{array}{l}\text { Melatonin counteracts changes in hypothalamic gene } \\
\text { expression of signals regulating feeding behavior in high-fat } \\
\text { fed rats }\end{array}$ & $\begin{array}{l}2.3 \mathrm{mg} / \mathrm{kg} \\
\text { p.o. }\end{array}$ & $25 \mathrm{mg}$ & $(70)$ \\
\hline $\begin{array}{l}\text { Melatonin reduces obesity and restores adipokine patterns } \\
\text { and metabolism in obese }(\mathrm{ob} / \mathrm{ob}) \text { mice }\end{array}$ & $\begin{array}{l}100 \mathrm{mg} / \mathrm{kg} \\
\text { p.o. }\end{array}$ & $610 \mathrm{mg}$ & (71) \\
\hline $\begin{array}{l}\text { Melatonin nephroprotective action in Zucker diabetic fatty } \\
\text { rats involves an inhibitory effect on NADPH oxidase }\end{array}$ & $\begin{array}{l}2.5 \mathrm{mg} / \mathrm{kg} \\
\text { p.o. }\end{array}$ & $25 \mathrm{mg}$ & (72) \\
\hline $\begin{array}{l}\text { Melatonin prevents type } 2 \text { diabetes in high carbohydrate } \\
\text { diet-fed male Wistar rats }\end{array}$ & $\begin{array}{l}0.8 \mathrm{mg} / \mathrm{kg} \\
\text { p.o. }\end{array}$ & $10 \mathrm{mg}$ & (73) \\
\hline $\begin{array}{l}\text { Melatonin decreases fasting blood glucose, total cholesterol, } \\
\text { LDL levels and MDA levels, and restores the vascular } \\
\text { responses and endothelial dysfunction in diabetic, high-fat } \\
\text { diet fed rats }\end{array}$ & $\begin{array}{l}10 \mathrm{mg} / \mathrm{kg} \\
\text { p.o. }\end{array}$ & $120 \mathrm{mg}$ & (74) \\
\hline $\begin{array}{l}\text { Maternal melatonin supplementation during murine diabetic } \\
\text { pregnancy improves the tolerance to myocardial } \\
\text { ischemia/reperfusion injury in the offspring, via restoring } \\
\text { cardiac IRS-1/Akt signaling }\end{array}$ & $\begin{array}{l}10 \mathrm{mg} / \mathrm{kg} \\
\text { p.o. }\end{array}$ & $60 \mathrm{mg}$ & (75) \\
\hline $\begin{array}{l}\text { In rats with diet-induced obesity exposed to circadian } \\
\text { disruption, treatment with melatonin alone or in } \\
\text { combination with metformin modifies progression of } \\
\text { metabolic dysfunction through improved adiposity, } \\
\text { circadian activity, insulin sensitivity, and islet cell failure }\end{array}$ & $\begin{array}{l}20 \mathrm{mg} / \mathrm{kg} \\
\text { p.o. }\end{array}$ & $240 \mathrm{mg}$ & (76) \\
\hline $\begin{array}{l}\text { Melatonin prevents non-alcoholic fatty liver disease in high- } \\
\text { fat diet induced obese mice by decreasing body weight and } \\
\text { reducing inflammation via modulation of the MAPK- } \\
\text { JNK/P38 signaling pathway }\end{array}$ & $\begin{array}{l}10 \mathrm{mg} / \mathrm{kg} \\
\text { p.o. }\end{array}$ & $60 \mathrm{mg}$ & (77) \\
\hline $\begin{array}{l}\text { Melatonin reverses liver apoptosis, mainly through intrinsic } \\
\text { pathway and reversed endoplasmic reticulum stress and } \\
\text { mitochondrial function in rats subjected to bile duct ligation }\end{array}$ & $\begin{array}{l}400 \mathrm{mg} / \mathrm{kg} \\
\text { i.p. }\end{array}$ & $4.85 \mathrm{~g}$ & (78) \\
\hline $\begin{array}{l}\text { Melatonin reduces body weight, liver steatosis, and low- } \\
\text { grade inflammation, and improves insulin resistance and gut } \\
\text { microbiota in high-fat diet fed mice }\end{array}$ & $\begin{array}{l}50 \mathrm{mg} / \mathrm{kg} \\
\text { p.o. }\end{array}$ & $300 \mathrm{mg}$ & (79) \\
\hline $\begin{array}{l}\text { The increased food intake, water consumption, } \\
\text { hyperglycemia, glucose intolerance, and insulin resistance } \\
\text { in T2DM rats were improved by melatonin or Neu-P11 } \\
\text { treatment. Treatment increased glucocorticoid receptor } \\
\text { expression and suppressed } 11 \beta \text {-hydroxysteroid } \\
\text { dehydrogenase } 1 \text { activity in the hippocampus by enhancing } \\
\text { glucocorticoid sensitivity and HPA feedback }\end{array}$ & $\begin{array}{l}20 \mathrm{mg} / \mathrm{kg} \\
\text { p.o. }\end{array}$ & $240 \mathrm{mg}$ & $(80)$ \\
\hline $\begin{array}{l}\text { Using mice fed a high-fat diet (HFD) as an obesity model, } \\
\text { spindle disorganization, chromosome misalignment, and } \\
\text { elevated reactive oxygen species (ROS) levels were } \\
\text { documented in oocytes from obese animals. Melatonin } \\
\text { administration not only reduces ROS generation, but }\end{array}$ & $\begin{array}{l}30 \mathrm{mg} / \mathrm{kg} \\
\text { p.o. }\end{array}$ & $180 \mathrm{mg}$ & (81) \\
\hline
\end{tabular}




\begin{tabular}{|l|c|c|c|}
\hline $\begin{array}{l}\text { prevents spindle/chromosome anomalies in oocytes, through } \\
\text { the SIRT3-SOD2-dependent mechanism consequently } \\
\text { promoting the developmental potential of early embryos. }\end{array}$ & & \\
\hline $\begin{array}{l}\text { Oral supplementation with melatonin reduces oxidative } \\
\text { damage and concentrations of inducible nitric oxide } \\
\text { synthase, VEGF and matrix metalloproteinase 9 in the } \\
\text { retina of rats with streptozotocin/nicotinamide induced pre- } \\
\text { diabetes }\end{array}$ & $\begin{array}{c}0.32 \mathrm{mg} / \mathrm{kg} \\
\mathrm{p} . \mathrm{o} .\end{array}$ & $4 \mathrm{mg}$ & $(82)$ \\
\hline $\begin{array}{l}\text { Melatonin counteracted oxidative damage, inflammation } \\
\text { and apoptotic cell death in lung tissue of diabetic rats. }\end{array}$ & $\begin{array}{c}20 \mathrm{mg} / \mathrm{kg} \\
\mathrm{p} . \mathrm{o} .\end{array}$ & $240 \mathrm{mg}$ & $(83)$ \\
\hline $\begin{array}{l}\text { Melatonin improves the therapeutic role of mesenchymal } \\
\text { stem cells on glucose, insulin, total antioxidant, and } \\
\text { malondialdehyde level in diabetic rats }\end{array}$ & $\begin{array}{c}10 \mathrm{mg} / \mathrm{kg} \\
\mathrm{p} . \mathrm{o} .\end{array}$ & $120 \mathrm{mg}$ & $(84)$ \\
\hline $\begin{array}{l}\text { Melatonin improves insulin resistance and hepatic steatosis } \\
\text { through attenuation of alpha-2-HS-glycoprotein in high-fat } \\
\text { diet mice. It reduced body weight gain and improved insulin } \\
\text { sensitivity and glucose intolerance by the upregulation of } \\
\text { muscle p-AKT protein expression. ER stress in the liver and } \\
\text { serum of HFD mice was decreased by melatonin treatment. }\end{array}$ & $\begin{array}{c}100 \mathrm{mg} / \mathrm{kg} \\
\mathrm{p} . \mathrm{o} .\end{array}$ & $1.2 \mathrm{~g}$ & $(85)$ \\
\hline $\begin{array}{l}\text { In diabetic rats melatonin prevented fluorescein leakage and } \\
\text { oxidative damage seen in the retina }\end{array}$ & $\begin{array}{c}20 \mathrm{mg} / \mathrm{kg} \\
\text { p.o. }\end{array}$ & $240 \mathrm{mg}$ & $(86)$ \\
\hline
\end{tabular}

As shown in Table 1, melatonin administration is usually very effective in reversing hyperadiposity in animal models of MS. The reasons for the decrease in body weight after melatonin in the absence of significant differences in food intake is worth to be explored. A key piece of evidence in this regard is the observation that melatonin plays a role in seasonal changes in adiposity by increasing the activity of the sympathetic nervous system innervating white and brown fat (87). Melatonin not only affects white adipose tissue, but also increases the recruitment of brown adipocytes and increases their metabolic activity in mammals (88-91). It was speculated that the hypertrophic effect and functional activation of brown adipose tissue induced by melatonin can likely be applied to treatment of human obesity.

From the doses of melatonin used in the experiment listed in Table 1, the human equivalent dose (HED) of melatonin for a $75 \mathrm{~kg}$ adult was calculated by normalization of body surface area (43). Body surface area correlates well across several mammalian species with several parameters of biology, including oxygen utilization, caloric expenditure, basal metabolism, blood volume, circulating plasma proteins, and renal function, and has been advocated as a factor to be used when converting a dose for translation from animals to humans (43). Noteworthy, theoretical human equivalent doses calculated from Table 1's results ranged from 2- to 3-orders of magnitude greater than those usually employed in humans.

Table 2 summarizes the effect of melatonin on animal models of ischemic and non-ischemic heart disease. One of the first observations derived from this laboratory. In a model of rat myocardial infarction (by ligation of the left anterior descending coronary artery for $3 \mathrm{~h}$ before) melatonin reduced $87 \%$ of the area of injury and $80 \%$ of the number of injured myocardial areas (92). Several studies indicated the efficacy of melatonin to reduce cardiac damage markers, to augment cardiac antioxidant defense system and to normalize the lipid profile in rats (93-99) and mice (100-102). The same was observed in cardiomyopathy induced by streptozotocin (103) or doxorubicin (104). In a murine model of myocardial infarction treated with cardiac progenitor cells, exposure of cells to melatonin enhances therapeutic efficacy of cardiac progenitor cells for myocardial infarction (105). Collectively, the results of Tables 1 and 2 indicate that the administration of melatonin effectively counteracts some of the 
disrupting effects seen in diet-induced obesity in animals insulin resistance, dyslipidemia and obesity, and the consequences of ischemic and non-ischemic heart disease.

Table 2. Effect of melatonin on animal models of ischemic and non-ischemic heart disease. The human equivalent dose (HED) of melatonin for a $75 \mathrm{~kg}$ adult is calculated by normalization of body surface area (43)

\begin{tabular}{|c|c|c|c|}
\hline Findings & $\begin{array}{l}\text { Melatonin } \\
\text { dose }\end{array}$ & $\begin{array}{l}\text { Daily HED } \\
\text { for a } 75 \mathrm{~kg} \\
\text { adult }\end{array}$ & Ref \\
\hline $\begin{array}{l}\text { In a model of rat myocardial infarction (by ligation of the } \\
\text { left anterior descending coronary artery for } 3 \mathrm{~h} \text { before) } \\
\text { melatonin reduced } 86-87 \% \text { of the area of injury and } 75- \\
80 \% \text { of the number of injured myocardial areas }\end{array}$ & $\begin{array}{c}6 \mathrm{mg} / \mathrm{kg} / \text { day } \\
\text { p.o. }\end{array}$ & $70 \mathrm{mg}$ & (92) \\
\hline $\begin{array}{l}\text { In a rat model of isoproterenol-induced myocardial } \\
\text { infarction, melatonin reduced cardiac damage markers, } \\
\text { augmented cardiac antioxidant defense system and } \\
\text { normalized the lipid profile }\end{array}$ & $\begin{array}{c}10 \mathrm{mg} / \mathrm{kg} / \text { day } \\
\text { i.p. }\end{array}$ & $120 \mathrm{mg}$ & (93) \\
\hline $\begin{array}{l}\text { In a rat model of severe obstructive sleep apnea, } \\
\text { melatonin was cardioprotective by decreasing BP, } \\
\text { oxidative stress, endothelial dysfunction, and } \\
\text { inflammation }\end{array}$ & $\begin{array}{c}10 \mathrm{mg} / \mathrm{kg} / \text { day } \\
\text { i.p. }\end{array}$ & $120 \mathrm{mg}$ & (94) \\
\hline $\begin{array}{l}\text { In a rat model of myocardial infarction-induced heart } \\
\text { failure, melatonin augmented cardiac activities of } \mathrm{Na}^{+} \text {, } \\
\mathrm{K}^{+} \text {-ATPase and SERCA, content of glutathione and levels } \\
\text { of caveolin-3, and reduced lactate dehydrogenase and } \\
\text { creatine kinase, lysosomal enzymatic activities and } \\
\text { cardiac malondialdehyde and myeloperoxidase }\end{array}$ & $\begin{array}{c}10 \mathrm{mg} / \mathrm{kg} / \text { day } \\
\text { i.p. }\end{array}$ & $120 \mathrm{mg}$ & (95) \\
\hline $\begin{array}{l}\text { In a rat model of hypoxic pulmonary hypertension with } \\
\text { intermittent hypoxia, melatonin decreased right } \\
\text { ventricular systolic pressures, the weight ratio } \mathrm{RV} / \mathrm{LV}+\mathrm{S} \text {, } \\
\text { pulmonary vascular structure remodeling; and several } \\
\text { signals involved in proliferation of primary pulmonary } \\
\text { artery smooth muscle cells }\end{array}$ & $\begin{array}{c}15 \mathrm{mg} / \mathrm{kg} / \text { day } \\
\text { i.p. }\end{array}$ & $180 \mathrm{mg}$ & (96) \\
\hline $\begin{array}{l}\text { In a rat model of isoproterenol-induced heart failure, } \\
\text { melatonin decreased cardiac fibrosis, oxidative stress, } \\
\text { insoluble and total collagen and the alteration of beta- } \\
\text { tubulin in the left ventricle }\end{array}$ & $\begin{array}{c}10 \mathrm{mg} / \mathrm{kg} / \text { day } \\
\text { p.o. }\end{array}$ & $120 \mathrm{mg}$ & (97) \\
\hline $\begin{array}{l}\text { In a rat model of arterial hypertension induced by } \\
\text { continuous light for } 6 \text { weeks, melatonin was } \\
\text { cardioprotective by decreasing cardiac fibrosis and } \\
\text { oxidative stress, but with no effect on left ventricle } \\
\text { hypertrophy }\end{array}$ & $\begin{array}{c}10 \mathrm{mg} / \mathrm{kg} / \text { day } \\
\text { p.o. }\end{array}$ & $120 \mathrm{mg}$ & (106) \\
\hline $\begin{array}{l}\text { In a rat model of pulmonary hypertension induced by } \\
\text { monocrotaline, melatonin exerted cardioprotection both } \\
\text { curative and preventive by decreasing right ventricular } \\
\text { hypertrophy, systemic oxidative stress and cardiac } \\
\text { interstitial fibrosis }\end{array}$ & $\begin{array}{c}6 \mathrm{mg} / \mathrm{kg} / \text { day } \\
\text { p.o. }\end{array}$ & $70 \mathrm{mg}$ & (98) \\
\hline
\end{tabular}




\begin{tabular}{|c|c|c|c|}
\hline $\begin{array}{l}\text { In a murine model of post-infarction, cardiac remodeling } \\
\text { and dysfunction, melatonin ameliorated cardiac } \\
\text { dysfunction; adverse left ventricle remodeling; autophagy, } \\
\text { apoptosis and mitochondrial dysfunction }\end{array}$ & $\begin{array}{l}20 \mathrm{mg} / \mathrm{kg} / \text { day } \\
\text { p.o. }\end{array}$ & $120 \mathrm{mg}$ & $(100)$ \\
\hline $\begin{array}{l}\text { In a murine model of myocardial infarction melatonin was } \\
\text { cardioprotective by reducing post- myocardial infarction } \\
\text { damage, Notch1 signaling and Mfn2 expression via } \\
\text { melatonin receptors }\end{array}$ & $\begin{array}{c}10-20 \\
\mathrm{mg} / \mathrm{kg} / \text { day i.p. }\end{array}$ & $\begin{array}{l}60-120 \\
\mathrm{mg}\end{array}$ & $(101)$ \\
\hline $\begin{array}{l}\text { In a murine model of myocardial infarction (ligation of } \\
\text { the left anterior descending coronary artery for } 5 \text { days) } \\
\text { melatonin decreased infarction damage by augmenting } \\
\text { PGC-1 } \alpha \text { and Tom } 70 \text { expression, preserving } \\
\text { mitochondrial integrity, and decreasing ROS production }\end{array}$ & $\begin{array}{c}10-20 \\
\mathrm{mg} / \mathrm{kg} / \text { day i.p. }\end{array}$ & $\begin{array}{l}60-120 \\
\mathrm{mg}\end{array}$ & (107) \\
\hline $\begin{array}{l}\text { In a murine model of pathological cardiac hypertrophy, } \\
\text { melatonin reduced pulmonary congestion, cardiac fibrosis } \\
\text { and the deterioration of cardiac contractile function }\end{array}$ & $\begin{array}{l}20 \mathrm{mg} / \mathrm{kg} / \mathrm{day} \\
\text { p.o. }\end{array}$ & $120 \mathrm{mg}$ & $(102)$ \\
\hline $\begin{array}{l}\text { In a model of rat diabetes mellitus, melatonin protects } \\
\text { against streptozotocin-induced diabetic cardiomyopathy } \\
\text { by the phosphorylation of vascular endothelial growth } \\
\text { factor-A. }\end{array}$ & $\begin{array}{l}50 \mathrm{mg} / \mathrm{kg} / \mathrm{day} \\
\text { i.p. }\end{array}$ & $600 \mathrm{mg}$ & (103) \\
\hline $\begin{array}{l}\text { In rats subjected to cardiac ischemia by coronary artery } \\
\text { ligation for } 30 \text { min and reperfusion for } 2 \mathrm{hr} \text { melatonin } \\
\text { attenuated myocardial ischemia/reperfusion Injury by } \\
\text { inhibiting autophagy via an AMPK/mTOR signaling } \\
\text { pathway }\end{array}$ & $20 \mathrm{mg} / \mathrm{kg}$ i.p. & $120 \mathrm{mg}$ & (108) \\
\hline $\begin{array}{l}\text { In a rat model of doxorubicin-induced cardiotoxicity, } \\
\text { melatonin improves cardiac and mitochondrial function } \\
\text { via peroxisome proliferator-activated receptor gamma } \\
\text { coactivator 1- } \text { aand sirtuin activity }\end{array}$ & $\begin{array}{l}6 \mathrm{mg} / \mathrm{kg} / \text { day } \\
\text { p.o. }\end{array}$ & $70 \mathrm{mg}$ & (104) \\
\hline $\begin{array}{l}\text { In a murine model of heart failure with preserved ejection } \\
\text { fraction melatonin improves cardiac function. }\end{array}$ & $\begin{array}{l}50 \mathrm{mg} / \mathrm{kg} / \mathrm{day} \\
\text { p.o. }\end{array}$ & $300 \mathrm{mg}$ & (109) \\
\hline $\begin{array}{l}\text { In a mouse model of myocarditis infected with coxsackie } \\
\text { virus B3 melatonin counteracted effectively myocardial } \\
\text { injuries }\end{array}$ & $\begin{array}{c}14.4 \\
\mathrm{mg} / \mathrm{kg} / \text { day i.p. }\end{array}$ & $88 \mathrm{mg}$ & (110) \\
\hline $\begin{array}{l}\text { In a murine model of diabetic cardiomyopathy, melatonin } \\
\text { activates Parkin translocation and rescues the impaired } \\
\text { mitophagy activity of through Mst } 1 \text { inhibition }\end{array}$ & 20 mg/kg i.p. & $120 \mathrm{mg}$ & (111) \\
\hline $\begin{array}{l}\text { In a rat model of overload-induced ventricular } \\
\text { hypertrophy caused by abdominal aortic constriction } \\
\text { melatonin prevented the changes in cardiofibrosis and in } \\
\text { gene expressions of HDAC } 1 \text {, HDAC } 2 \text {, HDAC } 3 \text {, HDAC } 4 \\
\text { in cardiomyocytes }\end{array}$ & $10 \mathrm{mg} / \mathrm{kg}$ i.p. & $60 \mathrm{mg}$ & $(112)$ \\
\hline $\begin{array}{l}\text { In a murine chronic pain induced by spared nerve injury } \\
\text { model followed by myocardial ischemia-reperfusion, } \\
\text { melatonin attenuated chronic pain related myocardial } \\
\text { ischemic susceptibility through inhibiting RIP3- } \\
\text { MLKL/CaMKII dependent necroptosis }\end{array}$ & $20 \mathrm{mg} / \mathrm{kg}$ i.p. & $120 \mathrm{mg}$ & (113) \\
\hline
\end{tabular}




\begin{tabular}{|l|l|l|l|}
\hline $\begin{array}{l}\text { In a rat model of cardiac ischemia/reperfusion after } \\
\text { ligation of descending coronary artery melatonin } \\
\text { treatment maintained myocardial function and } \\
\text { cardiomyocyte viability, and these effects were highly } \\
\text { dependent on mitochondrial fusion/mitophagy }\end{array}$ & $20 \mathrm{mg} / \mathrm{kg}$ i.p. & $120 \mathrm{mg}$ & (114) \\
\hline
\end{tabular}

As in the case of Table 1, the HED of melatonin for a $75 \mathrm{~kg}$ adult calculated by normalization of body surface area (43) yielded values greater than $60 \mathrm{mg}$ /day (Table 2). Interestingly, a recent study examining the subcellular distribution of the melatonin in the heart of rats indicates that at a dose of $40 \mathrm{mg} / \mathrm{kg}$ b.w, maximal concentration of melatonin was reached in the nucleus and mitochondrion. The authors concluded that doses of melatonin $\geq 112 \mathrm{mg}$ /day are required for therapeutic purpose $\mathrm{s}$ in a $70 \mathrm{~kg}$ adult (115).

\section{EVIDENCE FOR THE THERAPEUTIC VALUE OF MELATONIN IN ANIMAL MODELS OF AD}

The pathological signatures of $A D$ are the extracellular deposits of amyloid $B(A B)$-formed senile plaques and the intracellular accumulation of neurofibrillary tangles microtubules $(3,4)$. A $\beta$ plays an important role in the promotion of neuronal degeneration in AD neurons that become vulnerable to age-related increases in levels of oxidative stress and an altered cellular energy metabolism. Hyperphosphorylated tau protein promotes the assembly of microtubules and is an important factor in stabilizing microtubules $(3,4)$.

Cell line studies regarding $\mathrm{AD}$ and melatonin have delineated important melatonin mediated mechanisms in AD prevention. For a comprehensive review on melatonin activity to reverse disrupted signaling mechanisms in neurodegeneration, including proteostasis dysfunction, disruption of autophagic integrity, and anomalies in the insulin, Notch, and Wnt/ $\beta$-catenin signaling pathways see ref. (116).

Table 3 summarizes the effect of melatonin treatment in transgenic models of AD. The data are compatible with the view that melatonin regulates $A B$ metabolism mainly at the initial phases of the pathological process. From the doses of melatonin used in these different transgenic models, the HED of melatonin for a $75 \mathrm{~kg}$ adult can be calculated by normalization of body surface area (43). As for the experiments of Table 1, theoretical human equivalent doses calculated from Table 3's results ranged from 2- to 3-orders of magnitude greater than those employed in humans.

Table 3. Effect of melatonin on transgenic models of AD. The human equivalent dose (HED) of melatonin for a $75 \mathrm{~kg}$ adult is calculated by normalization of body surface area (43)

\begin{tabular}{|l|c|c|c|}
\hline \multicolumn{1}{|c|}{ Findings } & $\begin{array}{c}\text { Melatonin } \\
\text { dose }\end{array}$ & $\begin{array}{c}\text { Daily HED } \\
\text { for a 75 kg } \\
\text { adult }\end{array}$ & Ref. \\
\hline $\begin{array}{l}\text { In 4-month-old APP 695 transgenic mice treated with } \\
\text { melatonin for up to 15.5 months, partial inhibition of } \\
\text { expected elevation of } \beta \text {-amyloid, reduced abnormal } \\
\text { nitration of proteins, and increased survival were seen }\end{array}$ & $\begin{array}{c}50 \mathrm{mg} / \mathrm{kg} / \mathrm{day} \\
\text { p.o. }\end{array}$ & $\begin{array}{c}300 \\
\mathrm{mg} / \mathrm{day}\end{array}$ & $(117)$ \\
\hline $\begin{array}{l}\text { In 4-month-old APP 695 transgenic mice receiving } \\
\text { melatonin for 4 months, better learning and memory } \\
\text { performance and preserved choline acetyltransferase } \\
\text { activity in the frontal cortex and hippocampus were seen }\end{array}$ & $\begin{array}{c}10 \mathrm{mg} / \mathrm{kg} / \mathrm{day} \\
\text { p.o. }\end{array}$ & $60 \mathrm{mg} / \mathrm{day}$ & $(118)$ \\
\hline
\end{tabular}




\begin{tabular}{|c|c|c|c|}
\hline $\begin{array}{l}\text { In 14-month-old transgenic ( } \mathrm{Tg} 2576) \text { mice treatment with } \\
\text { melatonin for } 4 \text { months failed to produce antiamyloid or } \\
\text { antioxidant effects }\end{array}$ & $\begin{array}{c}3.6 \mathrm{mg} / \mathrm{kg} / \mathrm{day} \\
\text { p.o. }\end{array}$ & $20 \mathrm{mg} /$ day & (119) \\
\hline $\begin{array}{l}\text { In 4-month-old APP } 695 \text { transgenic mice treated for } 4 \\
\text { months melatonin prevented the increase of brain } \\
\text { thiobarbituric acid reactive substances, the decrease in } \\
\text { glutathione content, and the upregulation of the apoptotic- } \\
\text { related factors }\end{array}$ & $\begin{array}{c}10 \mathrm{mg} / \mathrm{kg} / \mathrm{day} \\
\text { p.o. }\end{array}$ & $60 \mathrm{mg} /$ day & (120) \\
\hline $\begin{array}{l}\text { In 5-month-old transgenic (Tg2576) mice exposed to } \\
\text { aluminum and melatonin for } 6 \text { months a lower habituation } \\
\text { pattern was observed in melatonin-treated animals. } \\
\text { Aluminum-treated } \mathrm{Tg} 2576 \text { mice showed impaired learning, } \\
\text { an effect unmodified by melatonin treatment }\end{array}$ & $\begin{array}{c}10 \mathrm{mg} / \mathrm{kg} / \mathrm{day} \\
\text { p.o. }\end{array}$ & $60 \mathrm{mg} /$ day & (121) \\
\hline $\begin{array}{l}\text { In 2-2.5-month-old APP/PS1 transgenic mice receiving } \\
\text { melatonin for } 5 \text { months, less cognitive impairment in } \\
\text { working memory and spatial reference learning/memory } \\
\text { was observed. Immunoreactive A } \beta \text { deposition was reduced } \\
\text { in hippocampus and entorhinal cortex of melatonin treated } \\
\text { transgenic mice }\end{array}$ & $\begin{array}{c}20 \mathrm{mg} / \mathrm{kg} / \mathrm{day} \\
\text { p.o. }\end{array}$ & $\begin{array}{c}120 \\
\mathrm{mg} / \mathrm{day}\end{array}$ & (122) \\
\hline $\begin{array}{l}\text { In 5-month-old transgenic (Tg2576) mice exposed to } \\
\text { aluminum and melatonin for } 6 \text { months the prooxidant } \\
\text { effect of aluminum in the hippocampus was prevented }\end{array}$ & $\begin{array}{c}10 \mathrm{mg} / \mathrm{kg} / \mathrm{day} \\
\text { p.o. }\end{array}$ & /day & (123) \\
\hline $\begin{array}{l}\text { In 9-month-old transgenic amyloid precursor protein } \\
\text { (APPSWE) mice given melatonin for } 4 \text { wk the temporal } \\
\text { pattern of anxiety-like behavior and time-dependent } \\
\text { changes in basal forebrain acetylcholinesterase expression } \\
\text { remained unmodified }\end{array}$ & $\begin{array}{c}1 \mathrm{mg} / \mathrm{kg} / \text { day } \\
\text { p.o. }\end{array}$ & /day & (124) \\
\hline $\begin{array}{l}\text { In 18-20-month-old APP/PS1 transgenic mice receiving } \\
\text { melatonin for } 1 \text { month less mitochondrial A } \beta \text { levels and a } \\
\text { near complete restoration of mitochondrial respiratory } \\
\text { rates, membrane potential, and ATP levels were observed } \\
\text { in hippocampus, cortex, or striatum. }\end{array}$ & $\begin{array}{c}20 \mathrm{mg} / \mathrm{kg} / \mathrm{day} \\
\text { p.o. }\end{array}$ & $\begin{array}{c}120 \\
\text { mg/day }\end{array}$ & (125) \\
\hline $\begin{array}{l}\text { In } 3.5 \text { - } 5.5 \text { month-old APP/PS1 transgenic mice receiving } \\
\text { melatonin or ramelteon for } 5.5 \text { months a significant } \\
\text { reduction in hippocampal protein oxidation was observed }\end{array}$ & $\begin{array}{c}5 \mathrm{mg} / \mathrm{kg} / \text { day } \\
\text { p.o. }\end{array}$ & g/day & (126) \\
\hline $\begin{array}{l}\text { In 11-12-month-old APPsw mice treated with melatonin } \\
\text { for } 1 \text { month a near complete restoration of brain } \\
\text { mitochondrial function was found }\end{array}$ & $\begin{array}{l}100 \\
\mathrm{mg} / \mathrm{kg} / \text { day } \\
\text { p.o. }\end{array}$ & $\begin{array}{c}600 \\
\text { mg/day }\end{array}$ & (127) \\
\hline $\begin{array}{l}\text { In 6-month-old 3xTg-AD mice treated with melatonin for } 6 \\
\text { months both melatonin and physical exercise decreased } \\
\text { soluble amyloid } \beta \text { oligomers, whereas only melatonin } \\
\text { decreased hyperphosphorylated tau. Both treatments } \\
\text { protected against cognitive impairment, brain oxidative } \\
\text { stress, and a decrease in mitochondrial DNA whereas the } \\
\text { combined treatment of physical exercise plus melatonin } \\
\text { was effective to protect mitochondrial complexes }\end{array}$ & $\begin{array}{c}10 \mathrm{mg} / \mathrm{kg} / \mathrm{day} \\
\text { p.o. }\end{array}$ & $60 \mathrm{mg} /$ day & (128) \\
\hline $\begin{array}{l}\text { Melatonin improved learning and spatial memory in 5- } \\
\text { month-old transgenic ( } \operatorname{Tg} 2576) \text { mice exposed for } 14 \\
\text { months to aluminum }\end{array}$ & $\begin{array}{c}10 \mathrm{mg} / \mathrm{kg} / \mathrm{day} \\
\text { p.o. }\end{array}$ & $60 \mathrm{mg} /$ day & (129) \\
\hline
\end{tabular}




\begin{tabular}{|l|c|c|c|}
\hline $\begin{array}{l}\text { In 4-month-old transgenic APP/PS1 mice administered } \\
\text { with a curcumin/melatonin hybrid (Z-CM-I-1) } 12 \text { weeks a } \\
\text { decreased accumulation of A } \beta \text { in the hippocampus and } \\
\text { cerebral cortex and reduced inflammatory responses and } \\
\text { oxidative stress were observed }\end{array}$ & $\begin{array}{c}50 \mathrm{mg} / \mathrm{kg} / \mathrm{day} \\
\text { of Z-CM-I-1 } \\
\mathrm{p} . \mathrm{o} .\end{array}$ & $\begin{array}{c}150 \\
\mathrm{mg} / \mathrm{day}\end{array}$ & (130) \\
\hline $\begin{array}{l}\text { In 10-month-old triple transgenic mice (3xTg-AD) } \\
\text { receiving melatonin for } 1 \text { month, amelioration of anxiety } \\
\text { and depression-like behaviors were observed }\end{array}$ & $\begin{array}{c}10 \mathrm{mg} / \mathrm{kg} / \mathrm{day} \\
\mathrm{p} . \mathrm{o} .\end{array}$ & $60 \mathrm{mg} / \mathrm{day}$ & $(131)$ \\
\hline $\begin{array}{l}\text { In 4-month-old transgenic (Tg2576) mice the } \\
\text { administration of melatonin augments the glymphatic } \\
\text { clearance of A } \beta\end{array}$ & $\begin{array}{c}100 \\
\mathrm{mg} / \mathrm{kg} / \mathrm{day} \\
\text { p.o. }\end{array}$ & $\begin{array}{r}600 \\
\mathrm{mg} / \mathrm{day}\end{array}$ & $(132)$ \\
\hline
\end{tabular}

The way in which melatonin exerts its inhibitory effect on the generation of $A \beta$ remains undefined. Melatonin interacts with $A \beta_{40}$ and $A \beta_{42}$ and inhibits progressive $\beta$-sheet and/or amyloid fibrils (133, 134), an interaction which appears to depend on structural melatonin characteristics rather than on its antioxidant properties (133). Via blockage of formation of secondary sheets, melatonin may facilitate peptide clearance by increasing proteolytic degradation.

Aß-induced neurotoxicity and cell death involves oxidative stress, and melatonin effectively protects cells against it in vitro $(135,136)$ and in vivo $(118,137-139)$. Protection from A $\beta$ toxicity by melatonin was observed, especially at the mitochondrial level.

Concerning tau hyperphosphorylation, melatonin efficiently attenuates it by affecting protein kinases and phosphatases in N2a and SH-SY5Y neuroblastoma cells exposed to wortmannin (140), calyculin A $(141,142)$ or okadaic acid $(143-145)$. Melatonin also antagonizes the oxidative stress that arises by the action of these agents $(146,147)$.

An important recent observation by Pappolla and co-workers indicate that the administration of melatonin to $\mathrm{AD}$ transgenic mice augments the glymphatic clearance of $\mathrm{A} \beta$ (132). Relevant to this, melatonin is known to preserve slow wave sleep in patients (148). During sleep, the elimination of A $\beta$ peptides increases considerably (149). Thus, the sleep disturbance found as a comorbidity in AD may contribute to the development and progression of the disease via a failure of $A \beta$ clearance (150).

Another factor in the pathogenesis of $\mathrm{AD}$ is the activation of microglia with the consequent increased expression of proinflammatory cytokines $(26,32)$, epidemiological studies suggesting that the use of anti-inflammatory drugs may decrease the incidence of $\operatorname{AD}(3,4)$. Melatonin attenuated the microglial production of proinflammatory cytokines induced by $\mathrm{A} \beta, \mathrm{NF} \mathrm{kB}$ and nitric oxide (139). In addition, the DNA binding activity of NF $\mathrm{kB}$ was inhibited by melatonin $(26,32)$.

\section{CLINICAL STUDIES ON MELATONIN THERAPEUTIC VALUE IN MS AND AD}

Type 2 diabetic patients have low circulating levels of melatonin (151) with a simultaneous and expected regulation of mRNA expression of the melatonin membrane receptor (152). In addition, allelic variants for melatonin receptors were associated with an increase in fasting blood glucose levels and / or an increased risk of type 2 diabetes (153-155) and with the polycystic ovarian syndrome (PCOS) (156).

Patients with coronary artery disease show a decrease in melatonin secretion (157-160) and among elderly hypertensive patients, nocturnal urinary melatonin excretion was inversely associated with the non-dipper pattern of hypertensive disease (161). Melatonin administration $(\leq 5 \mathrm{mg} /$ day) proved capable of reducing nocturnal blood pressure in hypertensives (162-165) and attenuated age-dependent disturbances of cardiovascular rhythms (166).

Treatment with melatonin $(\leq 5 \mathrm{mg}$ /day) improves MS in obese $(167,168)$ and PCOS patients $(169)$, as well as in bipolar and schizophrenic patients receiving second generation antipsychotics (170-172). The administration of melatonin normalizes MS in elderly hypertensive patients (173) and improves 
the enzyme profile in patients with alcoholic hepatic steatosis $(174,175)$. The combination of melatonin and zinc acetate, when used alone or in combination with metformin, improved the glycemic control in type 2 diabetic patients (176).

It must be noted that some results deny the capacity of melatonin to improve glucose tolerance and to reduce insulin resistance in humans. Melatonin administration in the morning decreased glucose tolerance, already in nondiabetic young individuals (177), an observation confirmed by recent studies $(178,179)$. In vitro, melatonin inhibits insulin secretion, an effect that is logical in humans if one presumes that melatonin suppresses insulin during the night to sensitize the pancreatic $\beta$-cells in preparation for breakfast. Additional information concerning a glucose tolerance-reducing property of melatonin in humans came from the detection of melatonin receptor polymorphisms. To date, several single nucleotide polymorphisms (SNPs) located near or inside the gene encoding MTNR1B with an association with type 2 diabetes mellitus have been identified in Asian (Indian, Sri Lankan, Chinese, Korean, Japanese) and European ethnicities (153, 180-185). Among these SNPs, rs10830963 appears the most strongly associated with an increase in fasting plasma glucose, glucose area under the curve, glycated hemoglobin (HbA1C) and a decrease in pancreatic $\beta$-cell function, basal insulin secretion and plasma insulin (186). This G allele that carries the SNP rs 10830963 is prodiabetic and is overexpressed in pancreatic $\beta$-cells, causing a more intense decrease in cyclic adenosine monophosphate (cAMP) upon melatonin stimulation and consequently suppressing more strongly the cAMP-dependent secretion of insulin (187). It appears to affect $\beta$-cell function directly and is associated with a defective early insulin response and a decreased $\beta$-cell glucose sensitivity (187-189). In clinical studies, the presence of the $G$ allele worsens the decrease in glucose tolerance induced by melatonin (190). However, it must be noted that a reduction in insulin secretion is not necessarily associated with insulin resistance in the target organs, clearly improved by melatonin in most studies. Moreover, other $\mathrm{MT}_{2}$ receptor variants with entirely different properties have been found to be also associated with type 2 diabetes. Some of them are dysfunctional because of their incapability of binding melatonin, and others were found to be unable to interact with $G_{i}$ proteins $(191,192)$. Thus, the absence of melatonin signaling is presumably diabetogenic.

An important point to consider in human studies is the discrimination of core symptoms (glucose homeostasis) from diabetes-associated pathologies, including those derived from an enhanced oxidative stress like liver steatosis, cardiovascular disease, retinopathy, nephropathy or osteoporosis. In most of these associated pathologies melatonin has a demonstrated therapeutic efficacy.

Concerning AD, CSF melatonin levels decrease even in preclinical stages of the disease when the patients do not manifest any cognitive impairment, suggesting that the reduction in CSF melatonin may be an early trigger and marker for AD (193). Although it is not known whether the relative melatonin deficiency is either a consequence or a cause of neurodegeneration, it seems clear that the loss in melatonin aggravates the disease and that early circadian disruption can be an important deficit to be considered. Significant differences were observed in melatonin levels between mild cognitive impairment (MCI) and $\mathrm{AD}$ patients with a negative correlation between neuropsychological assessment of dementia and melatonin levels (194).

Two recent meta-analyses endorsed the view that melatonin therapy is effective in improving sleep in patients with dementia $(195,196)$. Moreover, the melatonergic agonist ramelteon was reported as effective to treat delirium, an acute state of mental confusion that can lead to many adverse sequelae in intensive care unit elder patients (197).

Whether melatonin has any value in treating fully developed AD remains uncertain. It must be noted that one of the problems with AD patients with fully developed pathology is the heterogeneity of the group examined. Moreover, the reduced hippocampal expression of $\mathrm{MT}_{2}$ melatonin receptors in $\mathrm{AD}$ patients and of $\mathrm{MT}_{1}$ receptors in the circadian apparatus at later stages the disease may explain why melatonin treatment is less effective or erratic at this stage (198).

An analysis of published data of the use of melatonin in the early stages of cognitive decline consistently showed that administration of melatonin, every night before retiring, improves the quality 
of sleep and cognitive performance in this phase of the disease (199). In our Laboratory, we carried out a retrospective analysis of 25 patients with MCI who in the past three years had received a daily dose of 3-9 mg of melatonin along with their usual medication. Compared to an untreated group melatonin treated patients significantly improved cognitive and emotional performance and quality of sleep / wake rhythm (200). We also reported another series of 96 outpatients with a diagnosis of minimal cognitive impairment, 61 of who had received 3-24 mg of melatonin daily for 15 to 60 months. Patients treated with melatonin showed a significantly better performance in various neuropsychological tests. They also had lower scores in the Beck Depression Inventory concomitantly with improvement in the quality of sleep and wakefulness (201). Therefore, melatonin treatment can be effective in the early stages of neurodegenerative disease.

\section{CONCLUSIONS}

Melatonin exhibits both hypnotic and chronobiotic properties and has been used therapeutically for the treatment of insomnia related to age, as well as other primary and secondary insomnia $(202,203)$. Several meta-analyses support this role (204-206). A consensus of the British Association of Psychopharmacology on the evidence-based treatment of insomnia, parasomnia and sleep disorders in the circadian rhythm concluded that melatonin is the first-choice treatment when a hypnotic is indicated in patients older than 55 years (207).

As discussed in this article, studies using 2-5 mg of melatonin / day are not adequate to provide an adequate comparison with data on the protection of MS or AD derived from animal studies. Hence, clinical trials with doses in the 40-100 $\mathrm{mg}$ /day range are urgently needed

It should be noted that melatonin is remarkably non-toxic, and its safety is very high. The lethal dose 50 for the intraperitoneal injection of melatonin was determined for rats $(1168 \mathrm{mg} / \mathrm{kg})$ and mice (1131 mg / kg), but the oral administration of melatonin (tested up to $3200 \mathrm{mg} / \mathrm{kg}$ in rats) could not be determined and for melatonin subcutaneous injection (tested up to $1600 \mathrm{mg} / \mathrm{kg}$ in rats and mice) (208). In humans, melatonin has a high safety profile and, in general, is very well tolerated (Table 4).

Table 4. Safety for off label prescription of melatonin

\begin{tabular}{|l|l|c|}
\hline \multicolumn{1}{|c|}{ Clinical condition } & \multicolumn{1}{c|}{ Melatonin doses } & Ref. \\
\hline Dermal hyperpigmentation & $1 \mathrm{~g} /$ day p.o. for $1 \mathrm{month}$ & $(209)$ \\
\hline Parkinson's disease & $0.25 \mathrm{and} 1.25 \mathrm{mg} / \mathrm{kg}$ i.v. & $(211)$ \\
\hline Amyotrophic lateral sclerosis & $60 \mathrm{mg} /$ day p.o. for $13 \mathrm{months}$ & $(212)$ \\
\hline Amyotrophic lateral sclerosis & $300 \mathrm{mg} /$ day, rectal for 2 years & $(213)$ \\
\hline Muscular dystrophy & $70 \mathrm{mg} /$ day for 9 months & $(214)$ \\
\hline Multiple sclerosis & $50-300 \mathrm{mg} /$ day p.o. for 4 years & $(215)$ \\
\hline Liver surgery & $50 \mathrm{mg} / \mathrm{kg}$ & $(216)$ \\
\hline Healthy individuals & $80 \mathrm{mg} / \mathrm{hr}$ for $4 \mathrm{hr}$ & $(218)$ \\
\hline Healthy women & $300 \mathrm{mg} /$ day for 4 months & $(219)$ \\
\hline $\begin{array}{l}\text { Dose escalation in healthy } \\
\text { individuals }\end{array}$ & $10-100 \mathrm{mg}$ p.o. & $(220)$ \\
\hline $\begin{array}{l}\text { Dose escalation in healthy } \\
\text { individuals }\end{array}$ & $10-100 \mathrm{mg}$ p.o. & \\
\hline Resistant-trained athletes & $100 \mathrm{mg}$ p.o. for 4 weeks & \\
\hline
\end{tabular}


Unfortunately, the pharmaceutical industry is refractive to support those studies because of the lack of protective patents for a natural compound. Hence, only with the involvement of governmental and non-profit organizations such a goal can be achieved. At present, the only option for the attending physician interested in the use of melatonin as a cytoprotective is the off-label indication of the drug.

Off label use of medications are defined as the uses of medicines that are not included in the indications or dosing regimens listed by the administrative body that registers, controls and authorizes medications. the US Food and Drug Administration (221). The off label use of medications is common in many clinical areas, such as psychiatry, pediatrics, oncology and intensive care unit (222-225). In general, no law prohibits the unauthorized use of medicines and the prescription of unauthorized medicines is legally accepted in most legislations (226). The prescription of medications by physicians is limited only by the common requirement of physicians' duty to act and drive with care and attention.

In Argentina, the National Administration of Medicines, Food and Medical Technology (ANMAT) approved melatonin (3 mg capsules or tablets) as an over-the-counter drug in 1995. In 2017, ANMAT authorized a prolonged-release preparation of $2 \mathrm{mg}$ of melatonin $\left(\operatorname{Circadin}^{\mathrm{R}}\right.$ ) as a prescription medication. Although ANMAT cannot authorize the use of a drug for an indication that is not listed in the package leaflet, it does not mean that the indication of a drug for other clinical situations is prohibited. According to ANMAT, the unauthorized prescriptions are "the sole responsibility of the attending physician, who performs them in the full exercise of their professional activity, based on their experience and available scientific knowledge, motivated by the need to provide an answer to health problems for which there are no treatment standards or, if they exist, they are very difficult to access".

In many countries, melatonin is widely used as a dietary supplement or dietary products. The European Food Safety Authority (EFSA) has admitted that melatonin reduces sleep onset latency. This allows the introduction of melatonin as a food to improve the "regulation of the sleep-wake cycle", the "relaxation" and the "sleep patterns" $(227,228)$. Melatonin, melatonin-rich foods and their bio-extracts are now being developed to serve as nutritional supplements, dietary products and medications. The target group was defined by the EFSA as the general population and, as such, these extracts can be marketed in all EU countries.

Different studies indicate that, as in animal tissues, melatonin reduces oxidative stress in plants. In fact, its discovery in plants two decades ago has opened an emerging field of research that has made substantial progress in understanding the actions of melatonin that contribute to the ecological success of the plant. Overexpression of melatonin in plants facilitates the germination of seeds and improves the development and maturation of the roots, protecting plants from biotic and abiotic stress (229-231). Therefore, the presence of melatonin in plants has implications not only for plant growth and crop yield, but also in terms of human and animal nutrition. When plant products containing melatonin are consumed, the compound is easily absorbed and exerts its functions at the cellular level. Therefore, in animals and plants, melatonin is a highly useful molecule that neutralizes the physiopathological processes that compromise a healthy lifestyle. The enrichment of melatonin in foods seems to be necessary to achieve the amounts that provide effective protection. Therefore, an area of interest is the development of functional foods with high levels of melatonin. In parallel, the toxicity of long-term use of melatonin should be evaluated.

In conclusion, from studies in animals, several potentially useful effects of melatonin, such as those in $\mathrm{MS}$ and $\mathrm{AD}$, require high doses of melatonin to be evident. If melatonin is expected to be effective in improving health, especially in the elderly, it is likely that the low doses of melatonin commonly used are not very beneficial (232). The question of whether melatonin has a therapeutic value in the prevention or treatment of MS or AD deserves further analysis. Multicenter double-blind studies are needed to explore and further investigate the potential and utility of melatonin. The doses of melatonin used should be re-evaluated in view of the equivalent human doses of melatonin derived from preclinical data. Unfortunately, of the 64 clinical trials related to melatonin in an initial state 
(recruitment and non-recruitment) listed in PubMed (ClinicalTrials.gov Search results 01/05/2019) none is directed to this query.

\section{ACKNOWLEDGEMENT}

DPC is an Emeritus Superior Investigator from the Argentine National Research Council (CONICET) and Emeritus Professor, University of Buenos Aires.

\section{CONFLICT OF INTEREST}

The author declares that there are no commercial or financial relationships that could be construed as a potential conflict of interest.

\section{REFERENCES}

1. Smith CJ, Ryckman KK (2015) Epigenetic and developmental influences on the risk of obesity, diabetes, and metabolic syndrome. Diabetes Metab. Syndr. Obes. 8: 295-302.

2. O'Neill S, O'Driscoll L (2015) Metabolic syndrome: a closer look at the growing epidemic and its associated pathologies. Obes. Rev. 16: 1-12. doi.org/10.1111/obr.12229.

3. Jeong S (2017) Molecular and cellular basis of neurodegeneration in alzheimer's disease. Mol. Cells 40: 613-620. https://doi.org/10.14348/molcells.2017.0096.

4. Tan SH, et al. (2019) Emerging pathways to neurodegeneration: Dissecting the critical molecular mechanisms in Alzheimer's disease, Parkinson's disease. Biomed. Pharmacother. 111: 765-777. https://doi.org/10.1016/j.biopha.2018.12.101.

5. Prince M, et al. (2013) The global prevalence of dementia: a systematic review and metaanalysis. Alzheimers. Dement. 9: 63-75. https://doi.org/10.1016/j.jalz.2012.11.007.

6. Ferri CP, et al. (2005) Global prevalence of dementia: a Delphi consensus study. Lancet 366: 21122117. https://doi.org/10.1016/S0140-6736(05)67889-0.

7. Davies JMS et al. (2017) The Oxygen Paradox, the French Paradox, and age-related diseases. Geroscience. 39: 499-550. https://doi.org/10.1007/s11357-017-0002-y.

8. Tan DX, et al. (2014) Fundamental issues related to the origin of melatonin and melatonin isomers during evolution: relation to their biological functions. Int. J. Mol. Sci. 15: 15858-15890. https://doi.org/10.3390/ijms150915858.

9. Claustrat B, Leston J (2015) Melatonin: Physiological effects in humans. Neurochirurgie 61: 77 84. https://doi.org/10.1016/j.neuchi.2015.03.002.

10. Cardinali DP, Cano P, Jimenez-Ortega V, Esquifino AI (2011) Melatonin and the metabolic syndrome: physiopathologic and therapeutical implications. Neuroendocrinology 93: 133-142. https://doi.org/10.1159/000324699.

11. Cardinali DP, Hardeland R (2017) Inflammaging, metabolic syndrome and melatonin: a call for treatment studies. Neuroendocrinology 104: 382-397. https://doi.org/10.1159/000446543.

12. Tan DX, et al. (2015) Melatonin as a potent and inducible endogenous antioxidant: synthesis and metabolism. Molecules 20: 18886-18906. https://doi.org/10.3390/molecules201018886.

13. Hardeland R, Cardinali DP, Brown GM, Pandi-Perumal SR (2015) Melatonin and brain inflammaging. Prog. Neurobiol. 127-128: 46-63. https://doi.org/10.1016/j.pneurobio.2015.02.001.

14. Sharafati-Chaleshtori R, Shirzad H, Rafieian-Kopaei M, Soltani A (2017) Melatonin and human mitochondrial diseases. J. Res. Med. Sci. 22: 2. https://doi.org/10.4103/1735-1995.199092.

15. Cardinali DP (1981) Melatonin: A mammalian pineal hormone. Endocr. Rev. 2: 327-346.

16. Lavie P (1997) Melatonin: role in gating nocturnal rise in sleep propensity. J. Biol. Rhythms 12: 657-665. 
17. Lewy AJ, Emens J, Jackman A, Yuhas K (2006) Circadian uses of melatonin in humans. Chronobiol. Int. 23: 403-412. https://doi.org/10.1080/07420520500545862.

18. Pandi-Perumal SR, et al. (2008) Physiological effects of melatonin: role of melatonin receptors and signal transduction pathways. Prog. Neurobiol. 185: 335-353. https://doi.org/10.1016/j.pneurobio.2008.04.001.

19. Acuña-Castroviejo D, et al. (2014) Extrapineal melatonin: sources, regulation, and potential functions. Cell Mol. Life Sci. 71: 2997-3025. https://doi.org/10.1007/s00018-014-1579-2.

20. Reiter RJ, et al. (2017) Melatonin as a mitochondria-targeted antioxidant: one of evolution's best ideas. Cell Mol. Life Sci. 74: 3863-3881. https://doi.org/10.1007/s00018-017-2609-7.

21. Tan DX, Reiter RJ (2019) Mitochondria: the birth place, the battle ground and the site of melatonin metabolism. Melatonin Research 2: 44-66. https://doi.org/10.32794/mr11250011.

22. Hardeland R, et al. (2011) Melatonin--a pleiotropic, orchestrating regulator molecule. Prog. Neurobiol. 93: 350-384.

23. Dubocovich ML, et al. (2010) International union of basic and clinical pharmacology. LXXV. Nomenclature, classification, and pharmacology of $\mathrm{G}$ protein-coupled melatonin receptors. Pharmacol. Rev. 62: 343-380.

24. Cecon E, Oishi A, Jockers R (2017) Melatonin receptors: molecular pharmacology and signalling in the context of system bias. Br. J. Pharmacol. 175: 3263-3280. https://doi.org/10.1111/bph.13950.

25. Benitez-King G (2006) Melatonin as a cytoskeletal modulator: implications for cell physiology and disease. J. Pineal Res. 40: 1-9.

26. Hardeland R (2018) Recent findings in melatonin research and their relevance to the CNS. Cent. Nerv. Syst. Agents Med. Chem. 18: 102-114.

27. Venegas C, et al. (2013) Analysis of the daily changes of melatonin receptors in the rat liver. $J$. Pineal Res. 54: 313-321.

28. Reiter RJ, et al. (2018) Melatonin mitigates mitochondrial meltdown: interactions with SIRT3. Int. J. Mol. Sci. 19. pii: E2439. https://doi.org/10.3390/ijms19082439.

29. Manchester LC, et al. (2015) Melatonin: an ancient molecule that makes oxygen metabolically tolerable. J. Pineal Res. 59: 403-419. https://doi.org/10.1111/jpi.12267.

30. Galano A, Tan DX , Reiter RJ (2011) Melatonin as a natural ally against oxidative stress: a physicochemical examination. J. Pineal Res. 51: 1-16. https://doi.org/10.1111/j.1600079X.2011.00916.x.

31. Carrillo-Vico A, et al. (2013) Melatonin: buffering the immune system. Int. J. Mol. Sci. 14: 86388683. https://doi.org/10.1111/j.1600-079X.2011.00909.x.

32. Hardeland R (2018) Melatonin and inflammation-Story of a double-edged blade. J. Pineal Res. 65 : e12525. https://doi.org/10.1111/jpi.12525.

33. Cardinali DP, et al. (1980) Prostaglandin E release by rat medial basal hypothalamus in vitro. Inhibition by melatonin at submicromolar concentrations. Eur. J. Pharmacol. 67: 151-153.

34. Deng WG, Tang ST, Tseng HP, Wu KK (2006) Melatonin suppresses macrophage cyclooxygenase- 2 and inducible nitric oxide synthase expression by inhibiting p52 acetylation and binding. Blood 108: 518-524.

35. Costantino G, Cuzzocrea S, Mazzon E, Caputi AP (1998) Protective effects of melatonin in zymosan-activated plasma-induced paw inflammation. Eur. J. Pharmacol. 363: 57-63.

36. Pan M, Song YL, Xu JM, Gan HZ (2006) Melatonin ameliorates nonalcoholic fatty liver induced by high-fat diet in rats. J. Pineal Res. 41: 79-84. https://doi.org/10.1111/j.1600079X.2006.00346.x

37. Stumpf I, Bazwinsky I, Peschke E (2009) Modulation of the cGMP signaling pathway by melatonin in pancreatic beta-cells. J. Pineal Res. 46: 140-147. https://doi.org/10.1111/j.1600079X.2008.00638.x. 
38. Kanter M, Uysal H, Karaca T, Sagmanligil HO (2006) Depression of glucose levels and partial restoration of pancreatic beta-cell damage by melatonin in streptozotocin-induced diabetic rats. Arch. Toxicol. 80: 362-369. https://doi.org/10.1007/s00204-005-0055-z.

39. Nishida S, Sato R, Murai I, Nakagawa S (2003) Effect of pinealectomy on plasma levels of insulin and leptin and on hepatic lipids in type 2 diabetic rats. J. Pineal Res. 35: 251-256.

40. Nishida S, Segawa T, Murai I, Nakagawa S (2002) Long-term melatonin administration reduces hyperinsulinemia and improves the altered fatty-acid compositions in type 2 diabetic rats via the restoration of Delta-5 desaturase activity. J. Pineal Res. 32: 26-33.

41. Mazepa RC, Cuevas MJ, Collado PS, Gonzalez-Gallego J (2000) Melatonin increases muscle and liver glycogen content in nonexercised and exercised rats. Life Sci. 66: 153-160.

42. Shieh JM, Wu HT, Cheng KC, Cheng JT (2009) Melatonin ameliorates high fat diet-induced diabetes and stimulates glycogen synthesis via a PKCzeta-Akt-GSK3beta pathway in hepatic cells. J. Pineal Res. 47: 339-344. https://doi.org/10.1007/s00204-005-0055-z.

43. Reagan-Shaw S, Nihal M, Ahmad N (2008) Dose translation from animal to human studies revisited. FASEB J. 22: 659-661. https://doi.org/10.1096/fj.07-9574LSF.

44. Prunet-Marcassus B, et al. (2003) Melatonin reduces body weight gain in Sprague Dawley rats with diet-induced obesity. Endocrinology 144: 5347-5352.

45. Sartori C, et al. (2009) Melatonin improves glucose homeostasis and endothelial vascular function in high-fat diet-fed insulin-resistant mice. Endocrinology 150: 5311-5317. https://doi.org/10.1210/en.2009-0425.

46. Ladizesky MG, et al. (2003) Melatonin increases oestradiol-induced bone formation in ovariectomized rats. J. Pineal Res. 34: 143-151.

47. Sanchez-Mateos S, et al. (2007) Melatonin and estradiol effects on food intake, body weight, and leptin in ovariectomized rats. Maturitas https://doi.org/10.1016/j.maturitas.2007.06.006.

48. Ciortea R, et al. (2011) Effect of melatonin on intra-abdominal fat in correlation with endometrial proliferation in ovariectomized rats. Anticancer Res. 31: 2637-2643.

49. Raskind MA, et al. (2007) Olanzapine-induced weight gain and increased visceral adiposity is blocked by melatonin replacement therapy in rats. Neuropsychopharmacology 32: 284-288. https://doi.org/10.1038/sj.npp.1301093.

50. She M, et al. (2009) NEU-P11, a novel melatonin agonist, inhibits weight gain and improves insulin sensitivity in high-fat/high-sucrose-fed rats. Pharmacol. Res. 59: 248-253.

51. Rios-Lugo MJ, et al. (2010) Melatonin effect on plasma adiponectin, leptin, insulin, glucose, triglycerides and cholesterol in normal and high fat-fed rats. J. Pineal Res. 49: 342-348. https://doi.org/10.1111/j.1600-079X.2010.00798.x.

52. Cuesta S, et al. (2010) Melatonin improves inflammation processes in liver of senescenceaccelerated prone male mice (SAMP8). Exp. Gerontol. 45: 950-956. https://doi.org/10.1016/j.exger.2010.08.016.

53. Cuesta S, et al. (2013) Melatonin can improve insulin resistance and aging-induced pancreas alterations in senescence-accelerated prone male mice (SAMP8). Age (Dordr. ) 35: 659-671. https://doi.org/10.1007/s11357-012-9397-7.

54. Rodriguez MI, et al. (2008) Improved mitochondrial function and increased life span after chronic melatonin treatment in senescent prone mice. Exp. Gerontol. 43: 749-756. https://doi.org/10.1016/j.exger.2008.04.003.

55. Nduhirabandi F, et al. (2011) Chronic melatonin consumption prevents obesity-related metabolic abnormalities and protects the heart against myocardial ischemia and reperfusion injury in a prediabetic model of diet-induced obesity. J. Pineal Res. 50: 171-182. https://doi.org/10.1111/j.1600-079X.2010.00826.x.

56. Agil A, et al. (2011) Beneficial effects of melatonin on obesity and lipid profile in young Zucker diabetic fatty rats. J. Pineal Res. 50: 207-212. https://doi.org/10.1111/j.1600-079X.2010.00830.x. 
57. Kitagawa A, Ohta Y, Ohashi K (2012) Melatonin improves metabolic syndrome induced by high fructose intake in rats. J. Pineal Res. 52: 403-413. https://doi.org/10.1111/j.1600079X.2011.00955.x.

58. Cardinali DP, et al. (2013) Melatonin may curtail the metabolic syndrome: studies on initial and fully established fructose-induced metabolic syndrome in rats. Int. J. Mol. Sci. 14: 2502-2514. https://doi.org/10.3390/ijms14022502.

59. Bernasconi PA, et al. (2013) Melatonin and diet-induced metabolic syndrome in rats: impact on the hypophysial-testicular axis. Horm. Mol. Biol. Clin. Investig. 16: 101-112. https://doi.org/10.1515/hmbci-2013-0005.

60. Demirtas CY, et al. (2015) The investigation of melatonin effect on liver antioxidant and oxidant levels in fructose-mediated metabolic syndrome model. Eur. Rev. Med. Pharmacol. Sci. 19: 19151921.

61. Ewida SF, Al-Sharaky DR (2016) Implication of renal aquaporin-3 in fructose-induced metabolic syndrome and melatonin protection. J. Clin. Diagn. Res. 10: CF06-CF11. https://doi.org/10.7860/JCDR/2016/18362.7656.

62. Huang L, et al. (2013) Blood pressure reducing effects of piromelatine and melatonin in spontaneously hypertensive rats. Eur. Rev. Med. Pharmacol. Sci. 17: 2449-2456.

63. Vinogradova I, Anisimov V (2013) Melatonin prevents the development of the metabolic syndrome in male rats exposed to different light/dark regimens. Biogerontology. 14: 401-409. https://doi.org/10.1007/s10522-013-9437-4.

64. Hatzis G, et al. (2013) Melatonin attenuates high fat diet-induced fatty liver disease in rats. World J. Hepatol. 5: 160-169. https://doi.org/10.4254/wjh.v5.i4.160.

65. Agil A, et al. (2013) Melatonin ameliorates low-grade inflammation and oxidative stress in young Zucker diabetic fatty rats. J. Pineal Res. 54: 381-388. https://doi.org/10.1111/jpi.12012.

66. Bibak B, et al. (2014) Effects of melatonin on biochemical factors and food and water consumption in diabetic rats. Adv. Biomed. Res. 3: 173. https://doi.org/10.4103/2277-9175.139191.

67. Hidayat M, Maha Y, Wasim H (2015) Effect of melatonin on serum glucose and body weight in sotreptozotocin induced diabetes in albino rats. J. Ayub. Med. Coll. Abbottabad. 27: 274-276.

68. Pai SA, Majumdar AS (2014) Protective effects of melatonin against metabolic and reproductive disturbances in polycystic ovary syndrome in rats. J. Pharm. Pharmacol. 66: 1710-1721. https://doi.org/10.1111/jphp.12297.

69. Cano BP, et al. (2014) Melatonin normalizes clinical and biochemical parameters of mild inflammation in diet-induced metabolic syndrome in rats. J. Pineal Res. 57: 280-290. https://doi.org/10.1111/jpi.12168.

70. Rios-Lugo MJ, et al. (2015) Melatonin counteracts changes in hypothalamic gene expression of signals regulating feeding behavior in high-fat fed rats. Horm. Mol. Biol. Clin. Investig. 21: 175183. https://doi.org/10.1515/hmbci-2014-0041.

71. Favero G, et al. (2015) Melatonin reduces obesity and restores adipokine patterns and metabolism in obese (ob/ob) mice. Nutr. Res. 35: 891-900. https://doi.org/10.1016/j.nutres.2015.07.001.

72. Winiarska K, et al. (2016) Melatonin nephroprotective action in Zucker diabetic fatty rats involves its inhibitory effect on NADPH oxidase. J. Pineal Res. 60: 109-117 https://doi.org/10.1111/jpi.12296.

73. Doddigarla Z, Ahmad J, Parwez I (2016) Effect of chromium picolinate and melatonin either in single or in a combination in high carbohydrate diet-fed male Wistar rats. Biofactors 42: 106-114. https://doi.org/10.1002/biof.1253.

74. Salmanoglu DS, et al. (2016) Melatonin and L-carnitin improves endothelial disfunction and oxidative stress in Type 2 diabetic rats. Redox. Biol. 8: 199-204. https://doi.org/10.1016/j.redox.2015.11.007. 
75. Gao L, et al. (2016) The impaired myocardial ischemic tolerance in adult offspring of diabetic pregnancy is restored by maternal melatonin treatment. J. Pineal Res. 61: 340-352. https://doi.org/10.1111/jpi.12351.

76. Thomas AP, et al. (2016) Administration of melatonin and metformin prevents deleterious effects of circadian disruption and obesity in male rats. Endocrinology 157: 4720-4731. https://doi.org/10.1210/en.2016-1309.

77. Sun H, et al. (2016) Melatonin improves non-alcoholic fatty liver disease via MAPK-JNK/P38 signaling in high-fat-diet-induced obese mice. Lipids Health Dis. 15: 202. https://doi.org/10.1186/s12944-016-0370-9.

78. Sheen JM, et al. (2016) Melatonin alleviates liver apoptosis in bile duct ligation young rats. Int. J. Mol. Sci. 17: pii: E1365. https://doi.org/10.3390/ijms17081365.

79. Xu P, et al. (2017) Melatonin prevents obesity through modulation of gut microbiota in mice. $J$. Pineal Res. 62: e12399. https://doi.org/10.1111/jpi.12399.

80. Zhou J, et al. (2017) Neu-P11, a novel MT1/MT2 agonist, reverses diabetes by suppressing the hypothalamic-pituitary-adrenal axis in rats. Eur. J. Pharmacol. 812: 225-233. https://doi.org/10.1016/j.ejphar.2017.07.001.

81. Han L, et al. (2017) Melatonin protects against maternal obesity-associated oxidative stress and meiotic defects in oocytes via the SIRT3-SOD2-dependent pathway. J. Pineal Res. 63: e12431. https://doi.org/10.1111/jpi.12431.

82. Djordjevic B, et al. (2018) Oral supplementation with melatonin reduces oxidative damage and concentrations of inducible nitric oxide synthase, VEGF and matrix metalloproteinase 9 in the retina of rats with streptozotocin/nicotinamide induced pre-diabetes. Eur. J. Pharmacol. 833: 290297. https://doi.org/10.1016/j.ejphar.2018.06.011.

83. Onk D, et al. (2018) Effect of melatonin on antioxidant capacity, inflammation and apoptotic cell death in lung tissue of diabetic rats. Acta Cir. Bras. 33: 375-385. https://doi.org/10.1590/s0102865020180040000009.

84. Kadry SM, et al. (2018) Melatonin improves the therapeutic role of mesenchymal stem cells in diabetic rats. Toxicol. Mech. Methods 28: 529-538. https://doi.org/10.1080/15376516.2018.1471634.

85. Heo JI, et al. (2018) Melatonin improves insulin resistance and hepatic steatosis through attenuation of alpha-2-HS-glycoprotein. J. Pineal Res. 65: e12493. https://doi.org/10.1111/jpi.12493.

86. Mehrzadi S, et al. (2018) Protective effect of melatonin in the diabetic rat retina. Fundam. Clin. Pharmacol. 32: 414-421. https://doi.org/10.1111/fcp.12361.

87. Bartness TJ, Demas GE, Song CK (2002) Seasonal changes in adiposity: the roles of the photoperiod, melatonin and other hormones, and sympathetic nervous system. Exp. Biol. Med. (Maywood. ) 227: 363-376.

88. Tan DX, et al. (2011) Significance and application of melatonin in the regulation of brown adipose tissue metabolism: relation to human obesity. Obes. Rev. 12: 167-188. https://doi.org/10.1111/j.1467-789X.2010.00756.x.

89. de Souza CAP, et al. (2018) Melatonin multiple effects on brown adipose tissue molecular machinery. J. Pineal Res. 66: e12549. https://doi.org/10.1111/jpi.12549.

90. Fernandez VG, Reiter RJ, Agil A. (2018) Melatonin increases brown adipose tissue mass and function in Zucker diabetic fatty rats: implications for obesity control. J. Pineal Res. 64: e12472. https://doi.org/10.1111/jpi.12472.

91. Halpern B, et al. (2019) Melatonin Increases brown adipose tissue volume and activity in patients with melatonin deficiency: a proof-of-concept study. Diabetes 68: 947-952. https://doi.org/10.2337/db18-0956.

92. Castagnino HE, et al. (2002) Cytoprotection by melatonin and growth hormone in early rat myocardial infarction as revealed by Feulgen DNA staining. Neuro. Endocrinol. Lett. 23: 391-395. 
93. Patel V, Upaganlawar A, Zalawadia R, Balaraman R (2010) Cardioprotective effect of melatonin against isoproterenol induced myocardial infarction in rats: A biochemical, electrocardiographic and histoarchitectural evaluation. Eur. J. Pharmacol. 644: 160-168. https://doi.org/10.1016/j.ejphar.2010.06.065.

94. Hung MW, et al. (2013) Melatonin ameliorates endothelial dysfunction, vascular inflammation, and systemic hypertension in rats with chronic intermittent hypoxia. J. Pineal Res. 55: 247-256. https://doi.org/10.1111/jpi.12067.

95. Sehirli AO, et al. (2013) Melatonin protects against ischemic heart failure in rats. J. Pineal Res. 55: 138-148. https://doi.org/10.1111/jpi.12054.

96. Jin H, et al. (2014) Melatonin attenuates hypoxic pulmonary hypertension by inhibiting the inflammation and the proliferation of pulmonary arterial smooth muscle cells. J. Pineal Res. 57: 442-450. https://doi.org/10.1111/jpi.12184.

97. Simko F, et al. (2014) Melatonin reduces cardiac remodeling and improves survival in rats with isoproterenol-induced heart failure. J. Pineal Res. 57: 177-184. https://doi.org/10.1111/jpi.12154.

98. Maarman G, et al. (2015) Melatonin as a preventive and curative therapy against pulmonary hypertension. J. Pineal Res. 59: 343-353. https://doi.org/10.1111/jpi.12263.

99. Zhu P, et al. (2015) Melatonin protects ADSCs from ROS and enhances their therapeutic potency in a rat model of myocardial infarction. J. Cell Mol. Med. 19: 2232-2243. https://doi.org/10.1111/jcmm.12610.

100. Hu J, et al. (2017) Melatonin alleviates postinfarction cardiac remodeling and dysfunction by inhibiting Mst1. J. Pineal Res. 62: e12368. https://doi.org/10.1111/jpi.12368.

101. Pei H, et al. (2016) Melatonin prevents adverse myocardial infarction remodeling via Notch1/Mfn2 pathway. Free Radic. Biol. Med. 97: 408-417. https://doi.org/10.1016/j.freeradbiomed.2016.06.015.

102. Zhai M, et al. (2017) Melatonin protects against the pathological cardiac hypertrophy induced by transverse aortic constriction through activating PGC-1beta: In vivo and in vitro studies. $J$. Pineal Res. 63: e12433. https://doi.org/10.1111/jpi.12433

103. Behram KY, et al. (2018) Melatonin protects against streptozotocin-induced diabetic cardiomyopathy by the phosphorylation of vascular endothelial growth factor-A (VEGF-A). Cell Mol. Biol. (Noisy. -le-grand) 64: 47-52.

104. Govender J, Loos B, Marais E, Engelbrecht AM (2018) Melatonin improves cardiac and mitochondrial function during doxorubicin-induced cardiotoxicity: A possible role for peroxisome proliferator-activated receptor gamma coactivator 1-alpha and sirtuin activity? Toxicol. Appl. Pharmacol. 358: 86-101. https://doi.org/10.1016/j.taap.2018.06.031.

105. Ma W, et al. (2018) Pre-treatment with melatonin enhances therapeutic efficacy of cardiac progenitor cells for myocardial infarction. Cell Physiol. Biochem. 47: 1287-1298. https://doi.org/10.1159/000490224.

106. Simko F, et al. (2014) Melatonin reduces cardiac remodeling and improves survival in rats with isoproterenol-induced heart failure. J. Pineal Res. 57: 177-184. https://doi.org/10.1111/jpi.12154.

107. Pei HF, et al. (2017) Melatonin attenuates postmyocardial infarction injury via increasing Tom70 expression. J. Pineal Res. 62: e12371. https://doi.org/10.1111/jpi.12371.

108. Chen WR, et al. (2018) Melatonin attenuates myocardial ischemia/reperfusion injury by inhibiting autophagy via an AMPK/mTOR signaling pathway. Cell Physiol. Biochem. 47: 20672076. https://doi.org/10.1159/000491474.

109. Liu Y, et al. (2018) Melatonin improves cardiac function in a mouse model of heart failure with preserved ejection fraction. Redox. Biol. 18: 211-221. https://doi.org/10.1016/j.redox.2018.07.007.

110. Sang Y, et al. (2018) Melatonin ameliorates Coxsackievirus B3-induced myocarditis by regulating apoptosis and autophagy. Front Pharmacol. 9: 1384. https://doi.org/10.3389/fphar.2018.01384. 
111. Wang S, et al. (2018) Melatonin activates Parkin translocation and rescues the impaired mitophagy activity of diabetic cardiomyopathy through Mst1 inhibition. J. Cell Mol. Med. 22: 5132-5144. https://doi.org/10.1111/jcmm.13802.

112. Wu Y, et al. (2018) The effect of melatonin on cardio fibrosis in juvenile rats with pressure overload and deregulation of HDACs. Korean J. Physiol. Pharmacol. 22: 607-616. https://doi.org/10.4196/kjpp.2018.22.6.607.

113. Yang Z, et al. (2018) Melatonin attenuates chronic pain related myocardial ischemic susceptibility through inhibiting RIP3-MLKL/CaMKII dependent necroptosis. J. Mol. Cell Cardiol. 125: 185-194. https://doi.org/10.1016/j.yjmcc.2018.10.018.

114. Zhang Y, et al. (2018) Melatonin attenuates myocardial ischemia reperfusion injury via improving mitochondrial fusion/mitophagy and activating the AMPK-OPA1 signaling pathways. J. Pineal Res. 66: e12542. https://doi.org/10.1111/jpi.12542.

115. Acuña-Castroviejo D, Noguera-Navarro MT, Reiter RJ, Escames G (2018) Melatonin actions in the heart: more than a hormone. Melatonin Res 1: 21-26. Https://doi.org/10.32794/mr11250002.

116. Shukla M, Chinchalongporn V, Govitrapong P, Reiter RJ (2019) The role of melatonin in targeting cell signaling pathways in neurodegeneration. Ann. NY. Acad. Sci. 1443: 75-96. https://doi.org/10.1111/nyas.14005.

117. Matsubara E, et al. (2003) Melatonin increases survival and inhibits oxidative and amyloid pathology in a transgenic model of Alzheimer's disease. J. Neurochem. 85: 1101-1108.

118. Feng Z, et al. (2004) Melatonin alleviates behavioral deficits associated with apoptosis and cholinergic system dysfunction in the APP 695 transgenic mouse model of Alzheimer's disease. $J$. Pineal Res. 37: 129-136. https://doi.org/10.1111/j.1600-079X.2004.00144.x.

119. Quinn J, et al. (2005) Chronic melatonin therapy fails to alter amyloid burden or oxidative damage in old $\mathrm{Tg} 2576$ mice: implications for clinical trials. Brain Res. 1037: 209-213. https://doi.org/10.1016/j.brainres.2005.01.023.

120. Feng Z, Qin C, Chang Y, Zhang JT (2006) Early melatonin supplementation alleviates oxidative stress in a transgenic mouse model of Alzheimer's disease. Free Radic. Biol. Med. 40: 101-109. https://doi.org/10.1016/j.freeradbiomed.2005.08.014.

121. Garcia T, et al. (2009) Evaluation of the protective role of melatonin on the behavioral effects of aluminum in a mouse model of Alzheimer's disease. Toxicology 265: 49-55. https://doi.org/10.1016/j.tox.2009.09.009.

122. Olcese JM, et al. (2009) Protection against cognitive deficits and markers of neurodegeneration by long-term oral administration of melatonin in a transgenic model of Alzheimer disease. J. Pineal Res. 47: 82-96. https://doi.org/10.1111/j.1600-079X.2009.00692.x.

123. Garcia T, et al. (2010) Oxidative stress status and RNA expression in hippocampus of an animal model of Alzheimer's disease after chronic exposure to aluminum. Hippocampus 20: 218-225. https://doi.org/10.1002/hipo.20612.

124. Bedrosian TA, Herring KL, Weil ZM, Nelson RJ (2011) Altered temporal patterns of anxiety in aged and amyloid precursor protein (APP) transgenic mice. Proc. Natl. Acad. Sci. USA 108: 1168611691. https://doi.org/10.1073/pnas.1103098108.

125. Dragicevic N, et al. (2011) Melatonin treatment restores mitochondrial function in Alzheimer's mice: a mitochondrial protective role of melatonin membrane receptor signaling. J. Pineal Res. 51: 75-86. https://doi.org/10.1111/j.1600-079X.2011.00864.x.

126. Baño OB, et al. (2012) Circadian system functionality, hippocampal oxidative stress, and spatial memory in the APPswe/PS1dE9 transgenic model of Alzheimer disease: effects of melatonin or ramelteon. Chronobiol. Int. 29: 822-834. https://doi.org/10.3109/07420528.2012.699119.

127. Dragicevic N, et al. (2012) Caffeine increases mitochondrial function and blocks melatonin signaling to mitochondria in Alzheimer's mice and cells. Neuropharmacology 63: 1368-1379. https://doi.org/10.1016/j.neuropharm.2012.08.018 
128. Garcia-Mesa Y, et al. (2012) Melatonin plus physical exercise are highly neuroprotective in the 3xTg-AD mouse. Neurobiol. Aging 33: 1124-1129.

129. Di Paolo C, et al. (2014) Chronic exposure to aluminum and melatonin through the diet: neurobehavioral effects in a transgenic mouse model of Alzheimer disease. Food Chem. Toxicol. 69: 320-329. https://doi.org/10.1016/j.fct.2014.04.022.

130. Gerenu G, et al. (2015) Curcumin/melatonin hybrid 5-(4-hydroxy-phenyl)-3-oxo-pentanoic acid [2-(5-methoxy-1H-indol-3-yl)-ethyl]-amide ameliorates AD-like pathology in the APP/PS1 mouse model. ACS Chem. Neurosci. 6: 1393-1399. https://doi.org/10.1021/acschemneuro.5b00082.

131. Nie L, et al. (2017) Melatonin ameliorates anxiety and depression-like behaviors and modulates proteomic changes in triple transgenic mice of Alzheimer's disease. Biofactors 43: 593-611. https://doi.org/10.1002/biof.1369.

132. Pappolla MA, et al. (2018) Melatonin Treatment Enhances Abeta Lymphatic Clearance in a Transgenic Mouse Model of Amyloidosis. Curr. Alzheimer Res. 15: 637-642. https://doi.org/10.2174/1567205015666180411092551.

133. Poeggeler B, et al. (2001) Melatonin reverses the profibrillogenic activity of apolipoprotein E4 on the Alzheimer amyloid Abeta peptide. Biochemistry 40: 14995-15001.

134. Pappolla M, et al. (1998) Inhibition of Alzheimer beta-fibrillogenesis by melatonin. J. Biol. Chem. 273, 7185-7188.

135. Zatta P, Tognon G, Carampin P (2003) Melatonin prevents free radical formation due to the interaction between beta-amyloid peptides and metal ions [Al(III), $\mathrm{Zn}(\mathrm{II}), \mathrm{Cu}(\mathrm{II}), \mathrm{Mn}$ (II), $\mathrm{Fe}(\mathrm{II})$ ]. J. Pineal Res. 35: 98-103.

136. Feng Z, Zhang JT (2004) Protective effect of melatonin on beta-amyloid-induced apoptosis in rat astroglioma C6 cells and its mechanism. Free Radic. Biol. Med. 37: 1790-1801.

137. Furio AM, et al. (2002) Effect of melatonin on changes in locomotor activity rhythm of Syrian hamsters injected with beta amyloid peptide 25-35 in the suprachiasmatic nuclei. Cell Mol. Neurobiol. 22: 699-709.

138. Shen YX, et al. (2002) Melatonin blocks rat hippocampal neuronal apoptosis induced by amyloid beta-peptide 25-35. J. Pineal Res. 32: 163-167.

139. Rosales-Corral S, et al. (2003) Orally administered melatonin reduces oxidative stress and proinflammatory cytokines induced by amyloid-beta peptide in rat brain: a comparative, in vivo study versus vitamin C and E. J. Pineal Res. 35: 80-84.

140. Deng YQ, et al. (2005) Effects of melatonin on wortmannin-induced tau hyperphosphorylation. Acta Pharmacol. Sin. 26: 519-526.

141. Li SP, et al. (2004) Melatonin protects SH-SY5Y neuroblastoma cells from calyculin A-induced neurofilament impairment and neurotoxicity. J. Pineal Res. 36: 186-191.

142. Xiong YF, et al. (2011) Melatonin reduces the impairment of axonal transport and axonopathy induced by calyculin A. J. Pineal Res. 50: 319-327.

143. Benitez-King G, et al. (2003) Melatonin prevents cytoskeletal alterations and oxidative stress induced by okadaic acid in N1E-115 cells. Exp. Neurol. 182: 151-159.

144. Tunez I, et al. (2003) Protective melatonin effect on oxidative stress induced by okadaic acid into rat brain. J. Pineal Res. 34: 265-268.

145. Wang YP, et al. (2004) Melatonin ameliorated okadaic-acid induced Alzheimer-like lesions. Acta Pharmacol. Sin. 25: 276-280.

146. Liu SJ, Wang JZ (2002) Alzheimer-like tau phosphorylation induced by wortmannin in vivo and its attenuation by melatonin. Acta Pharmacol. Sin. 23: 183-187.

147. Wang XC, et al. (2005) Prevention of isoproterenol-induced tau hyperphosphorylation by melatonin in the rat. Sheng Li Xue Bao 57: 7-12.

148. Monti JM, et al. (1999) Polysomnographic study of the effect of melatonin on sleep in elderly patients with chronic primary insomnia. Arch. Gerontol. Geriatr. 28: 85-98. 
149. Boespflug EL, Iliff JJ (2018) The emerging relationship between interstitial fluid-cerebrospinal fluid exchange, amyloid-beta, and sleep. Biol. Psychiatry 83: 328-336. https://doi.org/10.1016/j.biopsych.2017.11.031.

150. Plog BA, Nedergaard M (2018) The glymphatic system in Central Nervous System health and disease: past, present, and future. Annu. Rev. Pathol. 13: 379-394. https://doi.org/10.1146/annurevpathol-051217-111018.

151. Tutuncu NB, et al. (2005) Melatonin levels decrease in type 2 diabetic patients with cardiac autonomic neuropathy. J. Pineal Res. 39: 43-49.

152. Peschke E, et al. (2007) Melatonin and type 2 diabetes - a possible link? J. Pineal Res. 42: 350358. https://doi.org/10.1111/j.1600-079X.2007.00426.x.

153. Prokopenko I, et al. (2009) Variants in MTNR1B influence fasting glucose levels. Nat. Genet. 41: 77-81. https://doi.org/10.1038/ng.290.

154. Huber M, et al. (2013) Genetics of melatonin receptor type 2 is associated with left ventricular function in hypertensive patients treated according to guidelines. Eur. J. Intern. Med. 24: 650-655. https://doi.org/10.1016/j.ejim.2013.03.015.

155. Zheng C, et al. (2015) A common variant in the MTNRlb gene is associated with increased risk of impaired fasting glucose (IFG) in youth with obesity. Obesity (Silver. Spring) 23: 1022-1029. https://doi.org/10.1002/oby.21030.

156. Song X, et al. (2015) Family association study between melatonin receptor gene polymorphisms and polycystic ovary syndrome in Han Chinese. Eur. J. Obstet. Gynecol. Reprod. Biol. 195: 108112. https://doi.org/10.1016/j.ejogrb.2015.09.043.

157. Sakotnik A, et al. (1999) Decreased melatonin synthesis in patients with coronary artery disease. Eur. Heart J. 20: 1314-1317.

158. Girotti L, et al. (2000) Low urinary 6-sulphatoxymelatonin levels in patients with coronary artery disease. J. Pineal Res. 29: 138-142.

159. Dominguez-Rodriguez A, et al. (2002) Decreased nocturnal melatonin levels during acute myocardial infarction. J. Pineal Res. 33: 248-252.

160. Yaprak M, et al. (2003) Decreased nocturnal synthesis of melatonin in patients with coronary artery disease. Int. J. Cardiol. 89: 103-107.

161. Obayashi K, et al. (2013) Nocturnal urinary melatonin excretion is associated with non-dipper pattern in elderly hypertensives. Hypertens. Res. 36: 736-740. https://doi.org/10.1038/hr.2013.20.

162. Cagnacci A, et al. (2005) Prolonged melatonin administration decreases nocturnal blood pressure in women. Am. J. Hypertens. 18: 1614-1618.

163. Scheer FA, et al. (2004) Daily nighttime melatonin reduces blood pressure in male patients with essential hypertension. Hypertension 43: 192-197.

164. Grossman E, et al. (2006) Melatonin reduces night blood pressure in patients with nocturnal hypertension. Am. J. Med. 119: 898-902.

165. Mozdzan M, et al. (2014) The effect of melatonin on circadian blood pressure in patients with type 2 diabetes and essential hypertension. Arch. Med. Sci. 10: 669-675. https://doi.org/10.5114/aoms.2014.44858.

166. Gubin DG, Gubin GD, Gapon LI, Weinert D (2016) Daily melatonin administration attenuates age-dependent disturbances of cardiovascular rhythms. Curr. Aging Sci. 9: 5-13.

167. Kozirog M, et al. (2011) Melatonin treatment improves blood pressure, lipid profile, and parameters of oxidative stress in patients with metabolic syndrome. J. Pineal Res. 50: 261-266. https://doi.org/10.1111/j.1600-079X.2010.00835.x.

168. Goyal A, et al. (2014) Melatonin supplementation to treat the metabolic syndrome: a randomized controlled trial. Diabetol. Metab. Syndr. 6: 124. https://doi.org/10.1186/1758-5996-6-124.

169. Tagliaferri V, et al. (2018) Melatonin treatment may be able to restore menstrual cyclicity in women with PCOS: a pilot study. Reprod. Sci. 25: 269-275. https://doi.org/10.1177/1933719117711262. 
170. Romo-Nava F, et al. (2014) Melatonin attenuates antipsychotic metabolic effects: an eight-week randomized, double-blind, parallel-group, placebo-controlled clinical trial. Bipolar. Disord. 16: 410-421. https://doi.org/10.1111/bdi.12196.

171. Modabbernia A, et al. (2014) Melatonin for prevention of metabolic side-effects of olanzapine in patients with first-episode schizophrenia: randomized double-blind placebo-controlled study. $J$. Psychiatr. Res. 53: 133-140. https://doi.org/10.1016/j.jpsychires.2014.02.013.

172. Mostafavi A, et al. (2014) Melatonin decreases olanzapine induced metabolic side-effects in adolescents with bipolar disorder: a randomized double-blind placebo-controlled trial. Acta Med. Iran 52: 734-739.

173. Shatilo VB, Bondarenko EV, Antoniuk-Shcheglova IA (2010) Pineal gland melatonin-producing function in elderly patients with hypertensive disease: age peculiarities. Adv. Gerontol. 23, 539542.

174. Gonciarz M, et al. (2012) The effects of long-term melatonin treatment on plasma liver enzymes levels and plasma concentrations of lipids and melatonin in patients with nonalcoholic steatohepatitis: a pilot study. J. Physiol. Pharmacol. 63: 35-40.

175. Gonciarz M, et al. (2010) The pilot study of 3-month course of melatonin treatment of patients with nonalcoholic steatohepatitis: effect on plasma levels of liver enzymes, lipids and melatonin. J. Physiol. Pharmacol. 61: 705-710.

176. Hussain SA, et al. (2006) Effects of melatonin and zinc on glycemic control in type 2 diabetic patients poorly controlled with metformin. Saudi. Med. J. 27: 1483-1488.

177. McMullan CJ, Curhan GC, Schernhammer ES , Forman JP (2013) Association of nocturnal melatonin secretion with insulin resistance in nondiabetic young women. Am. J. Epidemiol. 178: 231-238. https://doi.org/10.1093/aje/kws470.

178. Rubio-Sastre P, et al. (2014) Acute melatonin administration in humans impairs glucose tolerance in both the morning and evening. Sleep 37: 1715-1719. https://doi.org/10.5665/sleep.4088.

179. Eckel RH, et al. (2015) Morning circadian misalignment during short sleep duration impacts insulin sensitivity. Curr. Biol. 25: 3004-3010. https://doi.org/10.1016/j.cub.2015.10.011.

180. Matuszek MA, Anton A, Thillainathan S , Armstrong NJ (2015) Increased insulin following an oral glucose load, genetic variation near the melatonin receptor MTNR1B, but no biochemical evidence of endothelial dysfunction in young Asian men and women. PLoS One 10: e0133611. https://doi.org/10.1371/journal.pone.0133611.

181. Zhan Y, et al. (2015) Association between the rs4753426 polymorphism in MTNR1B with fasting plasma glucose level and pancreatic beta-cell function in gestational diabetes mellitus. Genet. Mol. Res. 14: 8778-8785. https://doi.org/10.4238/2015.

182. Tarnowski M, et al. (2017) MTNRIA and MTNRIB gene polymorphisms in women with $\begin{array}{lllll}\text { gestational } & \text { diabetes. } & \text { Gynecol. } & \text { Endocrinol. } & \text { 5: }\end{array}$ https://doi.org/10.1080/09513590.2016.1276556.

183. Dupuis J, et al. (2010) New genetic loci implicated in fasting glucose homeostasis and their impact on type 2 diabetes risk. Nat. Genet. 42: 105-116. https://doi.org/10.1038/ng.520.

184. Liao S, et al. (2012) Association of genetic variants of melatonin receptor 1B with gestational plasma glucose level and risk of glucose intolerance in pregnant Chinese women. PLoS One 7: e40113. https://doi.org/10.1371/journal.pone.0040113.

185. Liu C, et al. (2010) MTNRIB rs 10830963 is associated with fasting plasma glucose, HbA1C and impaired beta-cell function in Chinese Hans from Shanghai. BMC. Med. Genet. 11: 59. https://doi.org/10.1186/1471-2350-11-59.

186. Staiger H, et al. (2008) Polymorphisms within the novel type 2 diabetes risk locus MTNR1B determine beta-cell function. PLoS One 3: e3962. https://doi.org/10.1371/journal.pone.0003962. 
187. Lyssenko V, et al. (2009) Common variant in MTNR1B associated with increased risk of type 2 diabetes and impaired early insulin secretion. Nat. Genet. 41: 82-88. https://doi.org/10.1038/ng.288.

188. Langenberg C, et al. (2009) Common genetic variation in the melatonin receptor $1 \mathrm{~B}$ gene $(M T N R 1 B)$ is associated with decreased early-phase insulin response. Diabetologia 52: 1537-1542. https://doi.org/10.1007/s00125-009-1392-x.

189. Marchetti P, et al. (2012) From genotype to human beta cell phenotype and beyond. Islets 4: 323332. https://doi.org/10.4161/isl.22282.

190. Garaulet M, et al. (2015) Common type 2 diabetes risk variant in MTNR1B worsens the deleterious effect of melatonin on glucose tolerance in humans. Metabolism 64: 1650-1657. https://doi.org/10.1016/j.metabol.2015.08.003.

191. Bonnefond A, et al. (2012) Rare MTNR1B variants impairing melatonin receptor 1B function contribute to type 2 diabetes. Nat. Genet. 44: 297-301. https://doi.org/10.1038/ng.1053.

192. Karamitri A, et al. (2013) Minireview: Toward the establishment of a link between melatonin and glucose homeostasis: association of melatonin MT2 receptor variants with type 2 diabetes. Mol. Endocrinol. 27: 1217-1233. https://doi.org/10.1210/me.2013-1101.

193. Liu RY, et al. (1999) Decreased melatonin levels in postmortem cerebrospinal fluid in relation to aging, Alzheimer's disease, and apolipoprotein E-epsilon4/4 genotype. J. Clin. Endocrinol. Metab. 84: 323-327.

194. Sirin FB, et al. (2015) Plasma 8-isoPGF2 $\alpha$ and serum melatonin levels in patients with minimal cognitive impairment and Alzheimer disease. Turk. J. Med. Sci. 45: 1073-1077.

195. Xu J, et al. (2015) Melatonin for sleep disorders and cognition in dementia: a meta-analysis of randomized controlled trials. Am. J. Alzheimers Dis. Other Demen. 30: 439-447. https://doi.org/10.1177/1533317514568005.

196. Zhang W, et al. (2016) Exogenous melatonin for sleep disorders in neurodegenerative diseases: a meta-analysis of randomized clinical trials. Neurol. Sci. 37: 57-65. https://doi.org/10.1007/s10072-015-2357-0.

197. Furuya M, et al. (2012) Marked improvement in delirium with ramelteon: five case reports. Psychogeriatrics 12: 259-262. https://doi.org/10.1111/j.1479-8301.2012.00422.x.

198. Wu YH, et al. (2007) Decreased MT1 melatonin receptor expression in the suprachiasmatic nucleus in aging and Alzheimer's disease. Neurobiol. Aging 28: 1239-1247.

199. Cardinali DP, et al. (2014) Melatonin therapy in patients with Alzheimer's disease. Antioxidants 3: $245-277$. https://doi.org/10.3390/antiox3020245.

200. Furio AM, Brusco LI , Cardinali DP (2007) Possible therapeutic value of melatonin in mild cognitive impairment. A retrospective study. J. Pineal Res. 43: 404-409.

201. Cardinali DP, et al. (2012) Therapeutic application of melatonin in mild cognitive impairment. Am. J. Neurodegen. Dis. 1: 280-291.

202. Leger D, Laudon M, Zisapel N (2004) Nocturnal 6-sulfatoxymelatonin excretion in insomnia and its relation to the response to melatonin replacement therapy. Am. J. Med. 116: 91-95.

203. Zhdanova IV, et al. (2001) Melatonin treatment for age-related insomnia. J. Clin. Endocrinol. Metab. 86: 4727-4730.

204. Ferracioli-Oda E, Qawasmi A, Bloch MH (2013) Meta-analysis: melatonin for the treatment of primary sleep disorders. PLoS One 8: e63773. https://doi.org/10.1371/journal.pone.0063773.

205. Auld F, et al. (2017) Evidence for the efficacy of melatonin in the treatment of primary adult sleep disorders. Sleep Med. Rev. 34: 10-22. https://doi.org/10.1016/j.smrv.2016.06.005.

206. Li T, et al. (2019) Exogenous melatonin as a treatment for secondary sleep disorders: A systematic review and meta-analysis. Front Neuroendocrinol. 52: 22-28. https://doi.org/10.1016/j.yfrne.2018.06.004. 
207. Wilson SJ, et al. (2010) British Association for Psychopharmacology consensus statement on evidence-based treatment of insomnia, parasomnias and circadian rhythm disorders. $J$. Psychopharmacol. 24: 1577-1601. https://doi.org/10.1177/0269881110379307.

208. Sugden D (1983) Psychopharmacological effects of melatonin in mouse and rat. J. Pharmacol. Exp. Ther. 227: 587-591.

209. Nordlund JJ , Lerner AB (1977) The effects of oral melatonin on skin color and on the release of pituitary hormones. J. Clin. Endocrinol. Metab. 45: 768-774.

210. Anton-Tay F, Diaz JL, Fernandez-Guardiola A (1971) On the effect of melatonin upon human brain. Its possible therapeutic implications. Life Sci. I. 10: 841-850.

211. Jacob S, et al. (2002) Melatonin as a candidate compound for neuroprotection in amyotrophic lateral sclerosis (ALS): high tolerability of daily oral melatonin administration in ALS patients. $J$. Pineal Res. 33: 186-187.

212. Weishaupt JH, et al. (2006) Reduced oxidative damage in ALS by high-dose enteral melatonin treatment. J. Pineal Res. 41: 313-323.

213. Chahbouni M, et al. (2011) Melatonin treatment counteracts the hyperoxidative status in erythrocytes of patients suffering from Duchenne muscular dystrophy. Clin. Biochem. 44: 853858. https://doi.org/10.1016/j.clinbiochem.2011.04.001.

214. Lopez-Gonzalez A, et al. (2015) Melatonin treatment improves primary progressive multiple sclerosis: a case report. J. Pineal Res. 58: 173-177. https://doi.org/10.1111/jpi.12203.

215. Nickkholgh A, et al. (2011) The use of high-dose melatonin in liver resection is safe: first clinical experience. J. Pineal Res. 50: 381-388. https://doi.org/10.1111/j.1600-079X.2011.00854.x.

216. Waldhauser F, Saletu B , Trinchard-Lugan I (1990) Sleep laboratory investigations on hypnotic properties of melatonin. Psychopharmacology (Berl) 100: 222-226.

217. Voordouw BC, et al. (1992) Melatonin and melatonin-progestin combinations alter pituitaryovarian function in women and can inhibit ovulation. J. Clin. Endocrinol. Metab. 74: 108-117.

218. Galley HF, et al. (2014) Melatonin as a potential therapy for sepsis: a phase I dose escalation study and an ex vivo whole blood model under conditions of sepsis. J. Pineal Res. 56: 427-438. https://doi.org/10.1111/jpi.12134.

219. Harpsoe NG, Andersen LP, Gogenur I, Rosenberg J (2015) Clinical pharmacokinetics of melatonin: a systematic review. Eur. J. Clin. Pharmacol. 71: 901-909. https://doi.org/10.1007/s00228-015-1873-4.

220. Leonardo-Mendonca RC, et al. (2015) The benefits of four weeks of melatonin treatment on circadian patterns in resistance-trained athletes. Chronobiol. Int. 32: 1125-1134. https://doi.org/10.3109/07420528.2015.1069830.

221. ASHP statement on the use of medications for unlabeled uses (1992). Am. J. Hosp. Pharm. 49: 2006-2008.

222. Alexander GC, et al. (2011) Increasing off-label use of antipsychotic medications in the United States, 1995-2008. Pharmacoepidemiol. Drug Saf. 20: 177-184. https://doi.org/10.1002/pds.2082.

223. Bazzano AT, et al. (2009) Off-label prescribing to children in the United States outpatient setting. Acad. Pediatr. 9: 81-88. https://doi.org/10.1016/j.acap.2008.11.010.

224. Smithburger P L, et al. (2015) A multicenter evaluation of off-label medication use and associated adverse drug reactions in adult medical ICUs. Crit. Care Med. 43: 1612-1621. https://doi.org/10.1097/CCM.0000000000001022.

225. Saiyed MM, Ong PS, Chew L (2017) Off-label drug use in oncology: a systematic review of literature. J. Clin. Pharm. Ther. 42: 251-258. https://doi.org/10.1111/jcpt.12507.

226. Aagaard L, Kristensen K (2018) Off-label and unlicensed prescribing in Europe: implications for patients' informed consent and liability. Int. J. Clin. Pharm. 40: 509-512. https://doi.org/10.1007/s11096-018-0646-4.

227. EFSA Panel on Dietetic Products, Nutrition and Allergies (NDA). Scientific Opinion on the substantiation of health claims related to melatonin and alleviation of subjective feelings of jet lag 
(ID 1953) and reduction of sleep onset latency, and improvement of sleep quality (ID 1953) pursuant to Article 13 of Regulation (EC) No 1924/20061. EFSA J. (2010), 8: 1461.

228. EFSA Panel on Dietetic Products, Nutrition and Allergies (NDA). Scientific Opinion on the substantiation of a health claim related to melatonin and reduction of sleep onset latency (ID 1698; 1780, 4080) pursuant to Article 13 of Regulation (EC) No 1924/2006. EFSA J. (2011) 9: 2241.

229. Tan DX, Zanghi BM, Manchester LC, Reiter RJ (2014) Melatonin identified in meats and other food stuffs: potentially nutritional impact. J. Pineal Res. 57: 213-218. https://doi.org/10.1111/jpi.12152.

230. Erland LA, Murch SJ, Reiter RJ, Saxena PK. (2015) A new balancing act: The many roles of melatonin and serotonin in plant growth and development. Plant Signal. Behav. 10: e1096469. https://doi.org/10.1080/15592324.2015.1096469.

231. Arnao MB, Hernandez-Ruiz,J (2015) Functions of melatonin in plants: a review. J. Pineal Res. 59: 133-150. https://doi.org/10.1111/jpi.12253.

232. Cardinali DP (2019) Melatonin as a chronobiotic/cytoprotector: its role in healthy aging. Biol. Rhythm Res. 50: 28-45. https://doi.org/10.1080/09291016.2018.1491200.

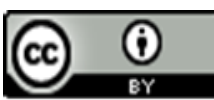

This work is licensed under a Creative Commons Attribution 4.0 International License

Please cite this paper as:

Cardinali, D. 2019. Are melatonin doses employed clinically adequate for melatonin

induced cytoprotection?. Melatonin Research. 2, 2 (Jun. 2019), 106-132.

DOI:https://doi.org/https://doi.org/10.32794/mr11250025. 